\title{
Review \\ Is Cognitive Functioning Impaired in Methamphetamine Users? A Critical Review
}

\author{
Carl L Hart* ${ }^{1,2,3}$, Caroline B Marvin', Rae Silver ${ }^{1,4,5}$ and Edward E Smith ${ }^{1,6}$ \\ 'Department of Psychology, Columbia University, New York, NY, USA; ${ }^{2}$ Division on Substance Abuse, New York State Psychiatric Institute and \\ Department of Psychiatry, College of Physicians and Surgeons of Columbia University, New York, NY, USA; ${ }^{3}$ Institute for Research in African- \\ American Studies, Columbia University, New York, NY, USA; ${ }^{4}$ Department of Psychology, Barnard College of Columbia University, New York, NY, \\ USA; ${ }^{5}$ Department of Anatomy and Cell Biology, Columbia University, New York, NY, USA; ${ }^{6}$ Division of Cognitive Neuroscience, New York State \\ Psychiatric Institute and Department of Psychiatry, College of Physicians and Surgeons, Columbia University, New York, NY, USA
}

\begin{abstract}
The prevailing view is that recreational methamphetamine use causes a broad range of severe cognitive deficits, despite the fact that concerns have been raised about interpretations drawn from the published literature. This article addresses an important gap in our knowledge by providing a critical review of findings from recent research investigating the impact of recreational methamphetamine use on human cognition. Included in the discussion are findings from studies that have assessed the acute and long-term effects of methamphetamine on several domains of cognition, including visuospatial perception, attention, inhibition, working memory, long-term memory, and learning. In addition, relevant neuroimaging data are reviewed in an effort to better understand neural mechanisms underlying methamphetamine-related effects on cognitive functioning. In general, the data on acute effects show that methamphetamine improves cognitive performance in selected domains, that is, visuospatial perception, attention, and inhibition. Regarding long-term effects on cognitive performance and brain-imaging measures, statistically significant differences between methamphetamine users and control participants have been observed on a minority of measures. More importantly, however, the clinical significance of these findings may be limited because cognitive functioning overwhelmingly falls within the normal range when compared against normative data. In spite of these observations, there seems to be a propensity to interpret any cognitive and/or brain difference(s) as a clinically significant abnormality. The implications of this situation are multiple, with consequences for scientific research, substance-abuse treatment, and public policy.

Neuropsychopharmacology (2012) 37, 586-608; doi:10.1038/npp.20 I I.276; published online I6 November 20 I I
\end{abstract}

Keywords: amphetamines; methamphetamine; cognition; impairment

\section{INTRODUCTION}

Amphetamine is a class of compounds that includes drugs used for both medical and recreational purposes. Of this class, $d$-amphetamine and methamphetamine are approved in several countries to treat a variety of disorders, including attention-deficit hyperactive disorder (ADHD), narcolepsy, and obesity. Over the past two decades, however, excessive illicit amphetamine use has become a major global concern. According to data from the United Nations Office on Drugs and Crime in 2008, amphetamine is used at rates higher than cocaine and heroin combined, and while use has stabilized somewhat in European, North American, and

*Correspondence: Dr CL Hart, New York State Psychiatric Institute at Columbia University, I05I Riverside Drive, Unit 120, New York, NY 10032, USA, Tel: + | 212543 5884, Fax: + | 212543 599|, E-mail: clh42@columbia.edu

Received 17 July 2011; revised 19 September 2011; accepted 9 October 2011
African countries, amphetamine is becoming increasingly popular in South and Central America and in the Near and Middle East (2008 Global ATS Assessment). Amphetamine use continues to be most prevalent in Oceania, North America, and East and Southeast Asia, where approximately $1-2 \%$ of the respective adult populations report annual use (2008 Global ATS Assessment). Like other illicit drug use, amphetamine use is associated with increased hospital admissions, treatment admissions, and arrests (Dobkin and Nicosia, 2009). In some countries, the perception of problems associated with the abuse (The terms 'abuse' and 'dependence', as they are used throughout this review, conform to the Diagnostic and Statistical Manual of Mental Disorders 4th Edition (DSM-IV-TR) and International Statistical Classification of Diseases and Related Health Problems (ICD-10) definitions of substance abuse and dependence. DSM-IV-TR and ICD-10 terminology are used to avoid the use of pejorative words and terminology that have multiple meanings.) of amphetamine has become so worrisome that drastic measures have been taken. 
In response to reports of precipitous increases in methamphetamine abuse, in 1996 the government of Thailand banned all uses of amphetamine, including those for medical purposes (Pilley and Perngparn, 1998). Other governments have also taken steps to restrict legal uses of amphetamine, although most have not been as extreme as those taken in Thailand. For example, in the United Kingdom and New Zealand, while $d$-amphetamine remains available for medical purposes, any use of methamphetamine (including medical use) has been banned.

There are several amphetamines used recreationally, including $d$-amphetamine, methamphetamine, 3,4-methylenedioxyamphetamine, and 3,4-methylenedioxymethamphetamine. Of these compounds, methamphetamine has generated the greatest amount of concern. Indeed, periodically there are statements in the scientific and popular literature attesting to methamphetamine's greater potency and 'addictive' potential, relative to other amphetamines. Such statements, however, are inconsistent with data collected in humans, which show that $d$-amphetamine and methamphetamine produce nearly identical physiological and behavioral effects (eg, Martin et al, 1971; Sevak et al, 2009; Kirkpatrick et al, in press a). One reason for the unfounded beliefs about the drugs might be related to the fact that methamphetamine is more readily available on the illicit market owing to its apparent easier synthesis. A quick search of the Internet can provide the surfer with dozens of 'How to make meth' recipes within minutes. According to these recipes and law enforcement personnel, methamphetamine can be 'easily' made from a few common products, the most important of which is the over-thecounter cold medication, pseudoephedrine. As a result, it is not surprising that methamphetamine is the most frequently abused amphetamine.

Methamphetamine abuse is associated with multiple deleterious medical consequences, including paranoia mimicking full-blown psychosis (Grelotti et al, 2010) and hypertensive crisis leading to stroke (Ho et al, 2009). While serious, such cases are rare, and entail the long-term use of extremely large doses. A more commonly described unfavorable effect associated with methamphetamine abuse is extreme tooth decay ('meth mouth'). Several reports describing this phenomenon have appeared in the scientific literature (for a review, see Hamamoto and Rhodus (2009)). In general, researchers conclude that methamphetamine restricts salivary flow leading to xerostomia (dry mouth). Because xerostomia can increase the likelihood of plaque and dental caries (tooth decay), this condition might underlie the dramatic pictures of 'meth mouth' seen in the popular media. Xerostomia is a relatively common side effect associated with many widely used medications, including the popular antidepressant Duloxetine (Cymbalta) and the ADHD medication $d$-amphetamine (Adderall: combination of amphetamine and $d$-amphetamine mixed salts). Despite the fact that these medications are used daily and frequently prescribed - each year both are among the top 100 most prescribed drugs in the United States (Bartholow, 2010)-there are no published reports of dental problems associated with their use. Given the structural and pharmacological similarities of methamphetamine and $d$-amphetamine, this suggests that the phenomenon of 'meth mouth' has less to do with the direct pharmacological effects of methamphetamine and more to do with non-pharmacological factors, ranging from poor dental hygiene to media sensationalism. Indeed, much of the evidence linking methamphetamine abuse and tooth decay is anecdotal; detailed investigations of the impact of methamphetamine abuse on dental health with suitable oral health assessments are lacking (ADA, 2005; Cretzmeyer et al, 2007; but see, Shetty et al, 2010).

Another frequently reported deleterious effect associated with methamphetamine abuse and dependence is cognitive impairment. Unlike the scant literature examining the effects of the drug on dental health, there is a burgeoning amount of information detailing the impact of methamphetamine on cognitive functioning. The dominant view is that illicit methamphetamine use causes a broad range of cognitive impairments (for a review, see Scott et al (2007)). Important shortcomings of the research perpetuating this perspective have received only limited attention. For example, in many of the studies the performance of methamphetamine abusers did not differ from controls on the majority of cognitive tasks employed. Importantly, although methamphetamine abusers performed significantly worse than controls on some cognitive tasks, their performance remained within the age- and educationmatched normal range. Furthermore, previous discussions of the impact of methamphetamine-related effects on human cognition have neglected data from research assessing the immediate effects of the drug on cognitive performance. These studies can provide crucial complementary information because they assess cognitive performance immediately before and after administration of the drug. The rationale for this approach is that if methamphetamine produces cognitive deficits, one might predict that methamphetamine-induced disruptions would be observed following acute administration of large doses.

This article addresses an important gap in our knowledge by providing a critical review of findings from recent research investigating the impact of recreational methamphetamine use on human cognition. The discussion of methamphetamine on cognition is divided into three main categories: (1) the acute effects that occur shortly after the drug has been administered and are assessed while the drug is still in the body; (2) the long-term effects of repeated use that are typically assessed when the drug is no longer in the body; and (3) finally, relevant neuroimaging data will be evaluated in an effort to shed light on the neural mechanisms underlying methamphetamine-related effects on cognitive functioning. The review begins with a brief overview of methamphetamine neuropharmacology.

\section{Methamphetamine Neuropharmacology}

Over the past several decades, data from basic research have contributed to an increased understanding of neuronal mechanisms involved in the effects of amphetamine, including methamphetamine. A comprehensive review of amphetamine neuropharmacology is beyond the scope of the current article, and excellent reviews already exist (eg, Sulzer et al, 2005; Fleckenstein et al, 2007). Nonetheless, a brief overview will provide insight into the neurotransmitters involved in the actions of amphetamine. As can be seen in Figure 1, amphetamine-related drugs bear a striking 
<smiles>NCCc1ccc(O)c(O)c1</smiles>

Norepinephrine<smiles>NCC(O)c1ccc(O)c(O)c1</smiles>

Amphetamine<smiles>CC(N)Cc1ccccc1</smiles><smiles>COc1ccc(CC(C)N)cc1OC</smiles>

Figure I Chemical structure of neurotransmitters and amphetamines.

resemblance to the catecholamine neurotransmitters dopamine (DA) and norepinephrine (NE). The structural similarities between amphetamine and catecholamine neurotransmitters provide clues about the drugs' mechanisms of action.

Multiple lines of evidence demonstrate that amphetamine causes release of monoamines from the neuronal cytosol via plasmalemmal uptake transporters, particularly the DA transporter (DAT), the NE transporter, and the serotonin (5-HT) transporter, an action often called 'reverse transport.' Although the actions of amphetamine on these transporters are generally comparable, most of the published research has focused on the DAT because it has been most often implicated in the reinforcing effects of this class of drug. Therefore, the discussion of plasmalemmal transporters herein focuses on the DAT.

Raiteri and co-workers (1979) provided early evidence suggesting that amphetamine increased DA release via a DAT mechanism when they showed that amphetamineinduced DA release was prevented by nomifensine, a DAT inhibitor. Subsequently, Zaczek et al (1991a,b) used rat brain synaptosomes to demonstrate active uptake of amphetamine by DAT. Strong support indicating that amphetamine analogs are substrates for the DAT came from a report by Sonders et al (1997), who used electrophysiological recording techniques to show that amphetamine elicited DA-like transporter-associated currents. Others replicated these findings (eg, Sitte et al, 1998), so that the evidence that amphetamine is accumulated by monoamine transporters is now quite strong. It is widely thought that amphetamine is selectively transported into cells and somehow causes DA, which normally is also taken up by these transporters, to be transported out. Although this is believed to occur because amphetamine changes the conformation of the transporters to favor reverse transport, the means by which this occurs are still unknown. Moreover, amphetamine blocks DA reuptake (Schmitz et al, 2002), illustrating that the actions of amphetamine are complex.

Methamphetamine<smiles>CNC(C)Cc1ccccc1</smiles>

3,4-Methylenedioxymethamphetamine (MDMA)<smiles>CNC(C)Cc1ccc(OC)c(OC)c1</smiles>

Another mechanism through which amphetamine causes DA release is by disrupting the activity of the vesicular monoamine transporter-2 (VMAT-2). One prominent perspective is that amphetamine administered in larger doses gains access to the neuron through the DAT and diffusion; once in the cell, it diffuses through the vesicular membrane and accumulates in vesicles, which disrupts the $\mathrm{pH}$ gradient required for vesicular DA sequestration, an action termed 'the weak base hypothesis.' However, amphetamine is also a VMAT-2 substrate, so that some of the drug is actively accumulated in the vesicles, and as with the DAT, acts as a competitive inhibitor and further disrupts the $\mathrm{pH}$ gradient. In any case, these actions cause DA to accumulate in the cytoplasm (Mosharov et al, 2009), which alters the concentration gradient and likely helps favor the reverse transport of DA via the DAT (for a review, see Sulzer et al (2005)).

An accumulating amount of evidence shows that amphetamine, when administered repeatedly in large doses, promotes the formation of reactive oxidative species. Following release of DA, the neurotransmitter is inactivated by monoamine oxidase-catalyzed oxidative deamination and may also undergo autoxidation. Both of these pathways have been shown to generate reactive oxidative species. Hence, abnormally enhanced DA activity has been hypothesized to produce an increased formation of oxidative stress and thereby cause cell injury (Cadet and Krasnova, 2009). This effect is particularly prominent within the cell cytosol. This, in turn, could lead to persistent deficits in dopaminergic functioning. Several researchers have found that large doses of methamphetamine, for example, decreased striatal DA content, DAT density, and the activity of tyrosine hydroxylase (DA rate-limiting enzyme) in laboratory animals (Cadet and Krasnova 2009).

This knowledge has raised concerns about the potential deleterious central nervous system consequences of methamphetamine abuse in humans, in part, because DA-rich areas subserve a wide range of important human 
functions ranging from movement to learning and memory. Indeed, a substantial database collected in laboratory animals suggests that acute and long-term administration of amphetamine produces disruptive effects in several cognitive domains (for a review, see Marshall et al (2007)). There is, however, an important limitation associated with many of these studies when extrapolating the findings to humans: the dosing regimens used did not capture key elements of human recreational amphetamine use, specifically gradual dose escalation. Typically, investigators administered large bolus doses of methamphetamine repeatedly for one or more consecutive days to drug-naïve animals, whereas human recreational drug users usually increase their doses gradually over time as their drug use progresses. This difference is not trivial because the deleterious neurobiological and behavioral changes that occur in response to repeated large doses of methamphetamine can be prevented with previous exposure to several days of escalating doses (Segal et al, 2003; O'Neil et al, 2006; Belcher et al, 2008). Given this situation, it is critically important to employ more ecologically relevant models in future animal studies investigating the impact of amphetamine use on cognitive functioning. These issues underscore the importance of carefully assessing cognition in human recreational methamphetamine users.

\section{Review of the Acute Effects of Methamphetamine on Cognition}

The influence of methamphetamine on cognitive functioning is highly dependent on the neurotransmitters and brain structures that are impacted by the drug. As noted above, acutely, methamphetamine causes a release of the monoamines DA, NE, and 5-HT. These neurotransmitters are produced in neurons located in the midbrain and brainstem and project widely throughout the brain. For example, DA is produced in both the substantia nigra and the ventral tegmental area (VTA). The substantia nigra sends projections to the dorsal striatum (caudate-putamen), and damage to this pathway has been implicated in Parkinson's disease. This pathway is also thought to play a crucial role in feedback-based reward learning (Shohamy et al, 2008). The VTA projects to the ventral striatum (nucleus accumbens and olfactory tubercle) and limbic structures and has been implicated in reward-related behaviors (Hyman et al, 2006). In addition, the VTA sends projections to the prefrontal cortex, which is known to play a role in a wide range of cognitive functions, including attention, inhibition, and working memory. Thus, it is possible that optimal levels of dopaminergic activity, that is, the amount produced by low to moderate oral doses of amphetamine, might actually improve functioning in some cognitive domains, including visuospatial perception, attention, and inhibition. Conversely, excessive dopaminergic activity, that is, the amount produced by large amphetamine doses administered repeatedly, might result not only in neurotoxic effects, but also might produce deficits in the abovementioned cognitive domains.

Effects of methamphetamine on performance of infrequent stimulant users. To better understand the direct pharmacological effects of methamphetamine on cognitive functioning, researchers typically assess performance immediately before, and repeatedly after, drug administration. Table 1 summarizes the studies that have evaluated the acute effects of methamphetamine on various domains of human cognition. These double-blind laboratory studies employ carefully controlled, within-participant designs, during which participants: (1) complete a baseline cognitive battery; (2) are administered a methamphetamine dose (ranging from placebo to $50 \mathrm{mg}$ ); and (3) are reassessed on the cognitive battery at predetermined time points for several hours after drug administration. In an earlier investigation of this type, Hart et al (2002) conducted an outpatient study in which participants who reported infrequent use of stimulants were administered oral methamphetamine $(0,5,10$, and $20 \mathrm{mg})$ and performance in various cognitive domains was assessed over the course of several weeks. Before beginning the study, participants received extensive training on the cognitive battery so that the tasks were well learned and performance was stable before any drug administration. The battery assessed performance in the domains of visuospatial perception, inhibition, long-term memory, and learning. It also included a measure of response speed (simple reaction time). Methamphetamine improved performance in the domains of learning and memory, visuospatial perception, and response speed; no drug-related disruptions were noted. These findings are consistent with data from investigations that have studied similar doses in individuals with limited stimulant drug experience (eg, Johnson et al, 2000; Silber et al, 2006; Marrone et al, 2010; Kirkpatrick et al (in press b), although there were no effects on any cognitive domains in a few studies (Comer et al, 2001; Hart et al, 2001; Sevak et al, 2009).

Effects of methamphetamine on performance of methamphetamine abusers. Although the above observations are congruent with the use of oral methamphetamine in the treatment of ADHD, a largely cognitive disorder characterized by deficits in attention and inhibition, they appear to be inconsistent with the view that methamphetamine causes disruptions in a range of cognitive functions. It is conceivable that the lack of acute methamphetamine-related disruptive effects on cognitive functioning in the studies described above may be related to the research participants studied and/or to the doses and route of drug administration examined. In the natural setting, for example, methamphetamine abusers' dose selection may not be guided by clinical recommendations and often exceeds doses tested in the laboratory. In addition, all of the above studies investigated the effects of methamphetamine administered orally, a route least often associated with drug abuse and toxicity in the natural setting, to non-drug abusers. Route of administration is a critical determinant of neurochemical consequences associated with stimulant administration, in part because neurochemical effects depend on the rate of the rise of drug concentrations and the maximum drug concentrations achieved (Gerasimov et al, 2000). Thus, it is possible that methamphetamine administered to abusers in larger doses and via routes other than oral, for example, intranasal or intravenous, might produce more disruptive effects on cognitive functioning. 
Table I Acute Effects of Methamphetamine Studies

\begin{tabular}{|c|c|c|c|c|c|}
\hline Investigators & Domain & $\begin{array}{l}\text { Methamphetamine } \\
\text { route and dose }\end{array}$ & Participants and design & Cognitive findings & Caveats \\
\hline Comer et al (200I) & $\begin{array}{l}\text { Immediate and long-term memory (digit- } \\
\text { recall task); visuospatial perception (DSST); } \\
\text { reaction time, vigilance, and inhibitory control } \\
\text { (DAT); sustained attention and inhibitory } \\
\text { control (RIT); leaming/memory (RAT) }\end{array}$ & Oral: $0,5,10 \mathrm{mg}$ & $\begin{array}{l}\text { Participants reported limited } \\
\text { experience with stimulants, but did not } \\
\text { meet the DSM-IV criteria for a MA-use } \\
\text { disorder } \\
N=7 \text { (within-subjects design) }\end{array}$ & $\begin{array}{l}\text { MA produced no consistent effects on } \\
\text { task performance }\end{array}$ & $\begin{array}{l}\text { Doses examined were lower than those used } \\
\text { recreationally } \\
\text { Route of administration used is not typically } \\
\text { associated with abuse } \\
\text { Small number of participants studied }\end{array}$ \\
\hline Hart et al (200I) & Same as above & Oral: $0,5,10 \mathrm{mg}$ & $\begin{array}{l}\text { Participants reported previous } \\
\text { experience with stimulants, but did not } \\
\text { meet the DSM-IV criteria for a MA-use } \\
\text { disorder } \\
N=8 \text { (within-subjects design) }\end{array}$ & $\begin{array}{l}\text { MA produced no consistent effects on } \\
\text { task performance }\end{array}$ & $\begin{array}{l}\text { Doses examined were lower than those used } \\
\text { recreationally } \\
\text { Route of administration used is not typically } \\
\text { associated with abuse } \\
\text { Small number of participants studied }\end{array}$ \\
\hline Hart et al (2002) & Same as above & Oral: $0,5,10,20 \mathrm{mg}$ & $\begin{array}{l}\text { Participants reported previous } \\
\text { experience with stimulants, but did not } \\
\text { meet the DSM-IV criteria for a MA use } \\
\text { disorder } \\
N=6 \text { (within-subjects design) }\end{array}$ & $\begin{array}{l}\uparrow \text { Visuospatial perception } \\
\uparrow \text { Reaction time } \\
\uparrow \text { Learning/memory } \\
\leftrightarrow \text { Immediate and long-term memory } \\
\leftrightarrow \text { Vigilance } \\
\leftrightarrow \text { Inhibitory control } \\
\leftrightarrow \text { Sustained attention }\end{array}$ & $\begin{array}{l}\text { Route of administration used is not typically } \\
\text { associated with abuse } \\
\text { Repeated-dosing effects were not investigated } \\
\text { Small number of participants studied }\end{array}$ \\
\hline Hart et al (2008) & Same as above & Intranasal: $0,12,25,50 \mathrm{mg} / 70 \mathrm{~kg}$ & $\begin{array}{l}\text { Participants met the DSM-IV criteria for } \\
\text { MA-use disorder } \\
N=11 \text { (within-subjects design) }\end{array}$ & $\begin{array}{l}\uparrow \text { Visuospatial perception } \\
\uparrow \text { Reaction time } \\
\uparrow \text { Vigilance } \\
\leftrightarrow \text { Immediate and long-term memory } \\
\leftrightarrow \text { Inhibitory control } \\
\leftrightarrow \text { Sustained attention } \\
\leftrightarrow \text { Learning/memory }\end{array}$ & Repeated-dosing effects were not investigated \\
\hline Johnson et al (2000) & $\begin{array}{l}\text { Sustained attention (RVIPT); conceptual } \\
\text { ability (LRT); psychomotor skill (FIT) }\end{array}$ & $\begin{array}{l}\text { Oral: } 0,0.21,0.42 \mathrm{mg} / \mathrm{kg} \\
\text { (equivalent dose: } \sim 15,30 \mathrm{mg} \text { ) }\end{array}$ & $\begin{array}{l}\text { Drug-naiive participants } \\
N=18 \text { (within-subjects design) }\end{array}$ & $\begin{array}{l}\uparrow \text { Sustained attention } \\
\uparrow \text { Conceptual ability } \\
\leftrightarrow \text { Psychomotor skill }\end{array}$ & $\begin{array}{l}\text { Route of administration used is not typically } \\
\text { associated with abuse } \\
\text { Repeated-dosing effects were not investigated }\end{array}$ \\
\hline Johnson et al (2005) & $\begin{array}{l}\text { Sustained attention (RVIPT); visuospatial } \\
\text { perception (DSST) }\end{array}$ & Intravenous: 0, 15, $30 \mathrm{mg}$ & $\begin{array}{l}\text { Participants met the DSM-IV criteria for } \\
\text { MA-use disorder } \\
N=19 \text { (within-subjects design) }\end{array}$ & $\begin{array}{l}\uparrow \text { Sustained attention } \\
\uparrow \text { Visuospatial perception }\end{array}$ & Repeated-dosing effects were not investigated \\
\hline Johnson et al (2007) & Same as above & Intravenous: 0, 15, $30 \mathrm{mg}$ & $\begin{array}{l}\text { Participants met the DSM-IV criteria for } \\
\text { MA-use disorder } \\
N=10 \text { (within-subjects design) }\end{array}$ & $\begin{array}{l}\uparrow \text { Sustained attention } \\
\uparrow \text { Visuospatial perception }\end{array}$ & Repeated-dosing effects were not investigated \\
\hline Kirkpatrick et al (2008) & Metacognition (Judgment of agency task) & Intranasal: 0, 12, 25, $50 \mathrm{mg} / 70 \mathrm{~kg}$ & $\begin{array}{l}\text { Participants met the DSM-IV criteria for } \\
\text { MA-use disorder } \\
N=10 \text { (within-subjects design) }\end{array}$ & $\uparrow$ Metacognition & Repeated-dosing effects were not investigate \\
\hline Kirkpatrick et al (in press) & $\begin{array}{l}\text { Immediate and long-term memory (digit- } \\
\text { recall task); visuospatial perception (DSST); } \\
\text { reaction time, vigilance and inhibitory control } \\
\text { (DAT); sustained attention and inhibitory } \\
\text { control (RIT); learning/memory (RAT) }\end{array}$ & Oral: $0,20,40 \mathrm{mg}$ & $\begin{array}{l}\text { Participants reported previous } \\
\text { experience with MA, but did not meet } \\
\text { the DSM-IV criteria for a MA-use } \\
\text { disorder } \\
N=11 \text { (within-subjects design) }\end{array}$ & $\begin{array}{l}\uparrow \text { Visuospatial perception } \\
\uparrow \text { Reaction time } \\
\uparrow \text { Vigilance } \\
\uparrow \text { Learning/memory } \\
\leftrightarrow \text { Immediate and long-term memory } \\
\leftrightarrow \text { Inhibitory control } \\
\leftrightarrow \text { Sustained attention }\end{array}$ & Repeated-dosing effects were not investigate \\
\hline Marrone et al (2010) & $\begin{array}{l}\text { Speech (quantity, fluency); speech perception } \\
\text { (ratings made by naïve listeners) }\end{array}$ & Oral: $0,20,40 \mathrm{mg}$ & $\begin{array}{l}\text { Participants reported previous } \\
\text { experience with MA, but did not meet } \\
\text { the DSM-IV criteria for a MA-use } \\
\text { disorder } \\
N=11 \text { (within-subjects design) }\end{array}$ & $\begin{array}{l}\uparrow \text { Speech } \\
\uparrow \text { Speech perception }\end{array}$ & Repeated-dosing effects were not investigate \\
\hline Mohs et al (1978) & $\begin{array}{l}\text { Information processing (visual search task); } \\
\text { Divided attention (DAT); Time estimation } \\
\text { (Time production task) }\end{array}$ & Oral: $0,10 \mathrm{mg}$ & $\begin{array}{l}\text { Participants' drug-use histories not } \\
\text { reported } \\
N=24 \text { (within-subjects design) }\end{array}$ & $\begin{array}{l}\uparrow \text { Information processing } \\
\leftrightarrow \text { Divided attention } \\
\leftrightarrow \text { Time estimation }\end{array}$ & $\begin{array}{l}\text { Only one active dose studied } \\
\text { Dose examined was lower than those used } \\
\text { recreationally }\end{array}$ \\
\hline
\end{tabular}


Table I Continued

Investigator

Mohs et al (1980) Learning/memory (Sternberg's memory
scanning task, Buschke's selective reminding
task): Time estimation (Time production Oral: $0,10 \mathrm{mg}$ task)

Rush et al (2011)

Visuospatial perception (DSST)

Intranasal: 0, 2.5, 5, 10, $20 \mathrm{mg}$ Participants met the DSM-IV stimulant-use disorde

Sevak et al (2009) Visuospatial perception (DSST)

Oral: $0,2.5,5,10,15 \mathrm{mg}$

All participants reported previous DSMIV use, but did not meet the $N=10$ (within-subjects design)

Silber et al (2006) Psychomotor function (Tracking task, TMT) working memory (Digit span forward and backward); sustained attention (Digit vigilance), simple attention (Movement estimation); visuospatial perception (DSST) Perceptual speed (Inspection time task)

Oral: $0,0.42 \mathrm{mg} / \mathrm{kg}$ (maximum

All participants reported previous mited stimulant use, but did not meet the DSM-IV criteria for a MA-use d,I-Methamphetamine: disorde

$\mathrm{N}=20$ (within-subjects design)

$\uparrow$ Sustained attention

$\uparrow$ Visuospatial perception

$\uparrow$ Psychomotor function (Tracking task)

$\leftrightarrow$ Psychomotor function (TMT)

$\leftrightarrow$ Working memory

$\leftrightarrow$ Perceptual speed

$\leftrightarrow$ Simple attention

$\uparrow$-methamphetamine:

$\uparrow$ Sustained attention

$\uparrow$ Perceptual speed

$\leftrightarrow$ Working memory

$\leftrightarrow$ Visuospatial processing (performed

worse than placebo in first session and

better than placebo in second)

$\leftrightarrow$ Psychomotor functio

$\leftrightarrow$ Simple attention

Talland and Quarton Shifting attention (Running digit span task) Intravenous: 0, $15 \mathrm{mg} / 68 \mathrm{~kg}$ (1965)

Participants' drug-use histories not

$\leftrightarrow$ Shifting attention

$N=18$ (within-subjects design)
Route of administration used is not typically associated with abuse

Repeated-dosing effects were not investigated

Only one active dose studied

Dose examined was lower than those used recreationally

Route of administration used is not typically associated with abuse

Repeated-dosing effects were not investigated

Repeated-dosing effects were not investigated

Doses examined were lower than those used recreationally

Route of administration used is not typically associated with abuse

Repeated-dosing effects were not investigated Only one active dose studied

Route of administration used is not typically associated with abuse

Repeated-dosing effects were not investigated

Only one active dose studied

Dose examined was lower than those used

recreationaly

Repeated-dosing effects were not investigated

Abbreviations: DAT, divided attention task; DSM-IV, Diagnostic and Statistical Manual of Mental Disorders 4th Edition; DSST, digit-symbol substitution task; FTT, finger tapping task; LRT, logical reasoning task, MA, methamphetamine; RAT, repeated acquisition task; RIT, rapid information task; RVIPT, rapid visual information processing task; TMT, Trail making task. 
Towards this end, we examined the impact of a range of intranasal methamphetamine doses, including doses larger than those previously investigated $(0,12,25$, and $50 \mathrm{mg} /$ $70 \mathrm{~kg}$ ), on the cognitive functioning of methamphetamine abusers (Hart et al, 2008). All active methamphetamine doses improved reaction time and sustained attention, but only the two intermediate doses ( 12 and $25 \mathrm{mg}$ ) significantly improved visuospatial perception. Importantly, methamphetamine-induced disruptions were not observed in any cognitive domain. These findings are similar to those from the few other intranasal studies, during which methamphetamine $(12 \mathrm{mg}$ ) enhanced metacognition (knowledge about the efficacy of one's own actions: Kirkpatrick et al, 2008) - and $(10,20 \mathrm{mg})$ improved visuospatial perception (Rush et al, 2011). Similar results have been reported when the drug was administered intravenously to methamphetamine abusers (Johnson et al, 2005, 2007). Anecdotally, methamphetamine is sometimes abused in a binge pattern (multiple doses administered repeatedly) at doses larger than those studied thus far (eg, Cho et al, 2001). Thus, it is possible that cognitive functioning would be disrupted, and not enhanced, following larger methamphetamine doses administered repeatedly. It is important to note, however, that methamphetamine doses tested in the studies described above are well within the range typically used by recreational users to produce euphoria and other desired effects. Nonetheless, future studies evaluating the effects of repeated methamphetamine administration on cognitive functioning are best suited to resolve this issue.

\section{Review of the Long-term Effects of Methamphetamine on Human Cognition}

Data from a growing number of laboratory studies have demonstrated that low and moderate doses of methamphetamine improve cognitive functioning in some domains, even when the drug is administered via routes associated with abuse. The impact of larger drug doses administered repeatedly over extended periods is less clear owing to ethical considerations that limit drug exposure during participation in laboratory studies. An alternative approach to determining possible detrimental effects of large methamphetamine doses on cognitive performance has been to study the brain and cognitive performance of abstinent long-term methamphetamine abusers. The idea is that regular use of illicit methamphetamine via routes other than oral administration over several years may result in neurotoxic effects, especially to monoamine neurons, which can have deleterious consequences on cognitive functioning. Below, we review studies that have: (1) combined brainimaging techniques with some cognitive tasks in an effort to correlate methamphetamine abusers' cognitive functioning with brain structure integrity and/or activity; and (2) employed comprehensive neuropsychological batteries to investigate methamphetamine abusers' cognitive functioning. We also include the few studies that have used positron emission tomography (PET) imaging (without testing any cognitive task) to investigate methamphetamine abusers' brain structure integrity and/or activity, because these studies have the potential to provide more specific information about methamphetamine-related DA neuro- toxicity. A caveat to this statement is that dopaminergic neuronal toxicity cannot be definitely determined in PET studies alone, as changes in tracer binding may reflect adaptation and not toxicity. (Studies that included HIV + individuals were excluded in an effort to minimize the impact of potentially confounding variables.)

PET studies investigating DAT and DA receptor availability of abstinent methamphetamine users. Because there are ample data collected in laboratory animals demonstrating that large repeated methamphetamine doses decrease several DA markers, including DAT density (eg, Cadet and Krasnova 2009), some have reasoned that longterm methamphetamine abuse by humans should produce a reduction in DAT density and DA receptor availability. Table 2 summarizes the studies that have used PET to assess differences in DAT and DA receptor availability when abstinent illicit methamphetamine users were compared with control participants. In one of the first studies of this type, McCann et al (1998) conducted a PET study using $\left[{ }^{11} \mathrm{C}\right] \mathrm{WIN}-35428$, a DAT ligand, to evaluate whether differences exist in striatal DAT density of methamphetamine users when compared with multiple other groups. Four groups of participants were studied: methamphetamine users $(N=6)$; methcathinone users $(N=4)$; Parkinson's disease patients $(N=3)$; and controls $(N=10)$. Methamphetamine users reported being abstinent for an average of $32 \pm 22( \pm S D)$ months before their study participation. Despite this extended period of abstinence, methamphetamine participants (as well as methcathinone users and Parkinson's disease patients) had significantly lower $\left[{ }^{11} \mathrm{C}\right]$ WIN-35428 binding potentials in both the caudate nucleus and putamen compared with control participants. It should be noted, however, that there was considerable overlap in the binding potentials of methamphetamine participants and control group individuals, that is, binding potential values for some methamphetamine users were equal to or higher than those of some individuals in the control group. Other caveats associated with this study included the small number of participants studied and the inability to control for the influence of other recreational drug use, that is, all methamphetamine participants reported using additional illicit drugs, making it impossible to isolate methamphetamine-induced effects on DAT availability.

In an attempt to minimize the impact of other illicit drug use, Sekine et al (2001) conducted a similar PET study in which Japanese methamphetamine users without other illicit drug-use histories $(N=11)$ were compared with a matched control group $(N=9)$. In general, their data were consistent with those obtained by McCann et al (1998) in that striatal DAT binding potentials were approximately $20 \%$ lower in methamphetamine users than in control participants. These findings suggest that the differential binding potential values obtained in the two studies were not attributable to other illicit drug use; both groups of researchers argued that the data lend support to the view that chronic illicit methamphetamine use produces persistent reductions in human DAT density that may be related to damage of striatal DA axons and axon terminals. Furthermore, these as well as other investigators 
Table 2 PET Studies

\begin{tabular}{|c|c|}
\hline Investigators & Domain tested \\
\hline \multicolumn{2}{|c|}{ Dopamine-related (DAT, D2/D3 receptor, VMAT-2) ligands } \\
\hline Boileau et al (2008) & $\begin{array}{l}\text { Attention/psychomotor function (TMT-A, } \\
\text { Grooved pegboard); Immediate and delayed } \\
\text { memory (CVLT); Working memory (Letter- } \\
\text { Number Sequencing and Visual Memory } \\
\text { Span-backwards subtests of WMS-III); } \\
\text { Set-shifting/executive function (TMT-B) } \\
\text { Note that the complete test battery was not } \\
\text { reported }\end{array}$ \\
\hline Johanson et al (2006) & $\begin{array}{l}\text { Attention/psychomotor function (TMT-A, } \\
\text { Grooved pegboard, Finger-tapping task, } \\
\text { Rapid visual information processing } \\
\text { (CANTAB)); Visuospatial perception } \\
\text { (DSST); Immediate and delayed memory } \\
\text { (CVLT, PAL); Working memory (Spatial } \\
\text { working memory and Delayed match to } \\
\text { sample tasks (CANTAB)); Set-shifting/ } \\
\text { executive function (TMT-B, Verbal fluency } \\
\text { test: FAS, Animal fluency, Intral } \\
\text { extradimensional shift and Stocking of } \\
\text { Cambridge tasks (CANTAB)) }\end{array}$ \\
\hline Lee et al (2009) & Cognitive testing not included \\
\hline
\end{tabular}
Grooved pegboard, Finger-tapping task Stroop);

Leaming/memory (WMS-III Logical

Memory); Working memory (Letter-Number Sequencing and Visual Memory Spaninhibition (Stroop); Set-shifting/executive function (TMT-B, WCST, Boston naming task, Verbal concept attainment scale, New adult reading test, Controlled oral word association test)
MA users met the DSM-IV criteria All had positive urine tests for $\mathrm{MA}$ dependence: $\mathrm{N}=22$ upon entry

MA users met the DSM-IV criteria for MA dependence: $N=16$

Mean: 3.4 years, range 3 months- 18 Controls: $N=18$ years (required 3-month minimum)

MA users met the DSM-IV criteria Mean: $19 \pm 24$ days MA Controls: $N=30$

MA users (diagnostic information Range 4-65 month not provided): $N=6$ Controls: $N=10$

Cognitive testing: Cognitive testing: mean $28.90 \pm 64.77$ not provided): $N=22$ Controls: $N=17$ MA users: $N=7$ MA users: $N=7$

Cognitive:

$\downarrow$ Attention/psychomotor functioning

$\downarrow$ Delayed memory

$\leftrightarrow$ Set-shifting/executive function

$\uparrow$ VMAT-2 BP in caudate, putamen, and ventral striatum

$\downarrow$ Visuospatial perception

$\downarrow$ Immediate and delayed memory

(CVLT only)

$\leftrightarrow$ Attention/psychomotor function

(3 out of 4 tests)

$\leftrightarrow$ Working memory

$\leftrightarrow$ Set-shifting/executive function

Brain:

$\downarrow$ DAT BP in all regions of the striatum (including caudate, putamen, and ventral striatum)

1 VMAT-2 BP in the striatum overal

(including caudate and anterior putamen)

Cognitive:

Not included

Brain:

D2/D3 BP in the striatum (caudate nucleus, putamen, and ventral striatum)

Cognitive:

Not included

Brain:

$\downarrow$ DAT BP in the caudate nucleus and putamen

$\leftrightarrow$ Attention/psychomotor function (3 out of 4)

$\leftrightarrow$ Learning/memory (3 out of 5)

$\leftrightarrow$ Working memory

$\leftrightarrow$ Set-shifting/executive function Brain:

$\downarrow$ DAT BP in the bilateral caudate and left putamen

Cognitive: Not included

MA users (diagnostic information Range 7 days-1.5 years not provided): $N=11$

Controls: $N=9$
Brain:

DAT BP in the striatum (caudate, putamen, and ventral striatum) and PFC

\section{Caveats}

Controls had higher levels of education

Cognitive data not compared against normative data set. Thus, the clinical importance of findings could not be determined

The influence of drug use other than MA not ontrolled

Small number of participants studied

MA users' cognitive performance on all tests fell within the normal range when data compared against normative data set

The influence of drug use other than MA not controlled

The influence of comorbid psychintric disorders Tuch as ADHD and deression not controlers such as ADHD and depression not controlled cogntions between inaging data and

of participants studied

Participant educational information not reported Relationship between cognitive functioning and brain activity could not be determined because no cognitive measure was included

The influence of drug use other than MA not controlled

Relationship between cognitive functioning and brain activity could not be determined because no cognitive measure was included

The influence of drug use other than MA not controlled

Small number of participants studied

Cognitive data not compared against normative data set. Thus, the clinical importance of findings could not be determined

The influence of drug use other than MA not controlled

The influence of comorbid psychiatric disorders such as ADHD and depression not controlled Small number of participants studied

Relationship between cognitive functioning and brain activity could not be determined because no cognitive measure was included Small number of participants studied 
Table 2 Continued

\begin{tabular}{|c|c|c|c|c|c|}
\hline Investigators & Domain tested & Participants & Period of abstinence & Cognitive and brain findings & Caveats \\
\hline Volkow et al (200 lb) & $\begin{array}{l}\text { Attention/psychomotor function (TMT-A, } \\
\text { Grooved pegboard, Timed gait task, Stroop, } \\
\text { CalCAP); Visuospatial perception (DSST); } \\
\text { Learning/memory (AVLT) }\end{array}$ & $\begin{array}{l}\text { MA users met the DSM-IV criteria } \\
\text { for MA dependence: } N=15 \\
\text { Controls: } N=18\end{array}$ & $\begin{array}{l}\text { Mean } 5.9 \pm 9.0 \text { months (required 2- } \\
\text { week minimum) }\end{array}$ & $\begin{array}{l}\text { Cognitive: Comparisons between the two } \\
\text { groups not reported, but significant } \\
\text { correlations between striatal DAT and } \\
\text { performance in some cognitive domains } \\
\text { were noted for the MA group (ie, } \\
\text { psychomotor function, learning/memory) } \\
\text { Brain: } \downarrow \text { DAT BP in the caudate and } \\
\text { putamen }\end{array}$ & $\begin{array}{l}\text { Participant educational information not reported } \\
\text { Cognitive data not compared against normative } \\
\text { data set. Thus, the clinical importance of findings } \\
\text { could not be determined } \\
\text { The influence of drug use other than MA not } \\
\text { controlled } \\
\text { Small number of participants studied }\end{array}$ \\
\hline Volkow et al (200Ic) & Cognitive testing not included & $\begin{array}{l}\text { MA users met the DSM-IV criteria } \\
\text { for MA dependence: } N=15 \\
\text { Controls: } N=20\end{array}$ & Data not reported & $\begin{array}{l}\text { Cognitive: Not included } \\
\text { Brain: } \downarrow \text { D2 BP in the caudate and putamen }\end{array}$ & $\begin{array}{l}\text { Participant educational information not reported } \\
\text { Relationship between cognitive functioning and } \\
\text { brain activity could not be determined because } \\
\text { no cognitive measure was included } \\
\text { The influence of drug use other than MA not } \\
\text { controlled } \\
\text { Small number of participants studied }\end{array}$ \\
\hline Volkow et al (200|d) & $\begin{array}{l}\text { Psychomotor function (Grooved pegboard, } \\
\text { Timed gait task); Learning/memory (AVLT) }\end{array}$ & $\begin{array}{l}\text { MA users met the DSM-IV criteria } \\
\text { for MA dependence: } N=5 \\
\text { evaluated twice (early and } \\
\text { protracted abstinence); } N=5 \\
\text { additional } \\
\text { Controls: } N=11\end{array}$ & $\begin{array}{l}\text { Early: mean } 3 \pm 1.6 \text { months } \\
\text { Protracted ( } 9 \text { months later): } 14 \pm 2 \\
\text { months } \\
\text { Other group: mean } 17 \pm 10 \text { months }\end{array}$ & $\begin{array}{l}\text { Cognitive: Comparisons between the MA } \\
\text { and control groups not reported } \\
\leftrightarrow \text { Cognitive performance was not altered } \\
\text { as a function of abstinence status } \\
\text { Brain: } \downarrow \text { DAT BP in the caudate and } \\
\text { putamen in early abstinence, relative to } \\
\text { controls } \\
\uparrow \text { DAT BP in the caudate and putamen } \\
\text { with protracted abstinence }\end{array}$ & $\begin{array}{l}\text { Participant educational information not reported } \\
\text { Cognitive data not compared against normative } \\
\text { data set. Thus, the clinical importance of findings } \\
\text { could not be determined } \\
\text { The influence of drug use other than MA not } \\
\text { controlled } \\
\text { Small number of participants studied }\end{array}$ \\
\hline
\end{tabular}

FDG ligand

Berman et al (2008) Vigilance (auditory vigilance task)

Kim et al (2005)

Set-shifting/executive function (WCST)

Kim et al (2009)

Same as above

London et al (2004)
MA users met the DSM-IV criteria Test I: mean $67 \pm 1.6$ days

for MA dependence: $N=10 \quad$ Test 2: mean $27.6 \pm 0.96$ days Controls: $N=12$

Cog
task) Brain: $\uparrow$ r the neocotex (in MA useen tests

$\leftrightarrow$ rCMRglc between tests I and 2 in subcortical regions (in MA users)

MA users met the DSM-IV criteria Mean 19.14 \pm 27.20 months (required for an MA-use disorder: $\mathrm{N}=35$ 4-week minimum) Controls: $\mathrm{N}=21$ males

$\leftrightarrow$ Set-shifting/executive function: females Brain: $\leftrightarrow$ rCMRglc levels in the right superior frontal WM (females)

$\downarrow$ rCMRglc levels in the right superior frontal WM (males)

MA users met the DSM-IV criteria Mean $20.5 \pm 8.3$ days (required I-week for an MA-use disorder: $\mathrm{N}=24 \quad$ minimum) Controls: $N=21$ (n) Brain: $\downarrow$ Metabolism in the left inferior frontal WM

MA users (diagnostic information Range 4-7 days not provided): $N=14$ Controls: $N=13$ Brain: $\leftrightarrow$ No difference in global glucose
Cognitive: $\leftrightarrow$ Attention/vigilance metabolism

Relative rCMRglc in infragenual ACC $\uparrow$ Activity in one cluster extending from middle to posterior portions of dorsal cingulate gyrus

$\uparrow$ Relative rCMRglc in the ventral striatum
Only one cognitive measure included The influence of drug use other than MA not controlled

Small number of participants studied

Controls had higher levels of education

Only one cognitive measure included and it was

not compared against normative data set, which

makes it difficult to determine the clinical

importance of findings

The influence of drug use other than MA not controlled

Controls had higher levels of education

Only one cognitive measure included and it was not compared against normative data set, which makes it difficult to determine the clinical

importance of findings

Performance on the WCST was not correlated with brain activity

Controls had higher levels of education

Only one cognitive measure included

The influence of drug use other than MA not controlled

Small number of participants studied 
Table 2 Continued

\begin{tabular}{|c|c|c|c|c|c|}
\hline Investigators & Domain tested & Participants & Period of abstinence & Cognitive and brain findings & Caveats \\
\hline London et al (2005) & Same as above & $\begin{array}{l}\text { MA users (diagnostic information } \\
\text { not provided): } N=17 \\
\text { Controls: } N=16\end{array}$ & Range 4-7 days & $\begin{array}{l}\text { Cognitive: } \downarrow \text { Attention/vigilance } \\
\text { Brain: MA users: Negative correlations } \\
\text { between error rates and relative activity in } \\
\text { anterior and middle cingulate gyrus and } \\
\text { insula } \\
\text { Controls: Positive correlations between } \\
\text { error rates and activity in the cingulate } \\
\text { cortex }\end{array}$ & $\begin{array}{l}\text { Controls had higher levels of education } \\
\text { Only one cognitive measure included and it wa } \\
\text { not compared against normative data set, whic } \\
\text { makes it difficult to determine the clinical } \\
\text { importance of findings } \\
\text { The influence of drug use other than MA not } \\
\text { controlled } \\
\text { Small number of participants studied }\end{array}$ \\
\hline Volkow et al (200la) & $\begin{array}{l}\text { Attention/psychomotor function (TMT-A, } \\
\text { Grooved pegboard, Timed gait task, Stroop, } \\
\text { CalCAP); Visuospatial perception (DSST); } \\
\text { Leaming/memory (AVLT) }\end{array}$ & $\begin{array}{l}\text { MA users met the DSM-IV criteria } \\
\text { for MA dependence: } N=15 \\
\text { Controls: } N=21\end{array}$ & Required 2-week minimum & $\begin{array}{l}\text { Cognitive: Results not reported } \\
\text { Brain: } \downarrow \text { Glucose metabolism in the } \\
\text { thalamus, caudate, and putamen } \\
\uparrow \text { Glucose metabolism in parietal cortex }\end{array}$ & $\begin{array}{l}\text { Participant educational information not reporte } \\
\text { Clinical importance and relationship between } \\
\text { cognitive functioning and brain activity could no } \\
\text { be determined because no cognitive results no } \\
\text { reported } \\
\text { The influence of drug use other than MA not } \\
\text { controlled } \\
\text { Small number of participants studied }\end{array}$ \\
\hline Wang et al (2004) & Same as above & $\begin{array}{l}\text { MA users met the DSM-IV criteria } \\
\text { for MA dependence: } N=5 \\
\text { evaluated twice (short and } \\
\text { protracted abstinence); } N=8 \\
\text { additional } \\
\text { Controls: } N=11\end{array}$ & $\begin{array}{l}\text { Short: mean } 3 \pm 1.6 \text { months } \\
\text { Protracted: } \\
\text { Original } 5 \text { MA users: mean } 14 \pm 2 \\
\text { months } \\
\text { Additional } 8 \text { MA users: mean } 17 \pm 10 \\
\text { months }\end{array}$ & $\begin{array}{l}\text { Cognitive: Comparisons between the two } \\
\text { groups not reported, but significant } \\
\text { correlations between thalamic activity } \\
\text { changes and performance in some cognitive } \\
\text { domains were noted for the MA group (ie, } \\
\text { psychomotor function (timed gait), learning/ } \\
\text { memory (delayed recall)) } \\
\text { Brain: MA users evaluated twice: } \\
\uparrow \text { Thalamic metabolism in protracted } \\
\text { abstinence relative to short abstinence } \\
\leftrightarrow \text { Global metabolism or absolute } \\
\text { metabolic measures in the striatum, } \\
\text { thalamus, or occipital cortex between short } \\
\text { (<6 months) and protracted (I2-17 } \\
\text { months) abstinence } \\
\leftrightarrow \text { Striatal metabolism in protracted } \\
\text { abstinence relative to short abstinence } \\
\text { Comparison with controls: } \\
\downarrow \text { Striatal metabolism in protracted } \\
\text { abstinence and short abstinence relative to } \\
\text { controls } \\
\downarrow \text { Thalamic metabolism in short abstinence } \\
\text { relative to controls } \\
\leftrightarrow \text { Absolute global brain metabolism } \\
\text { among short and protracted abstinence and } \\
\text { controls } \\
\leftrightarrow \text { Thalamic metabolism in protracted } \\
\text { abstinence relative to controls }\end{array}$ & $\begin{array}{l}\text { Participant educational information not reporte } \\
\text { Cognitive data not compared against normativ } \\
\text { data set. Thus, the clinical importance of finding } \\
\text { could not be determined } \\
\text { The influence of drug use other than MA not } \\
\text { controlled } \\
\text { Small number of participants studied }\end{array}$ \\
\hline
\end{tabular}

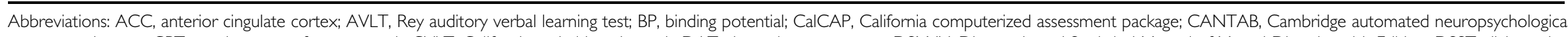

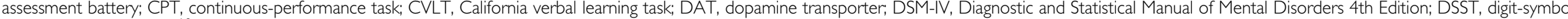

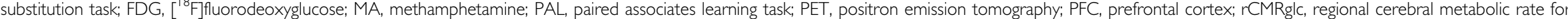

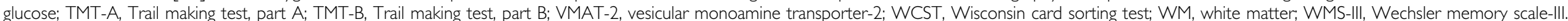
Cognitive performance: $\downarrow$, MA users performed more poorly than controls; $\leftrightarrow$, MA users and controls performed equally.

Brain activity: $\downarrow$, decreased activity in MA users; $\uparrow$, increased activity in MA users; $\leftrightarrow$, no difference in activity between MA users and controls 
(eg, Volkow et al, 2001b) have suggested that lower DAT density contributes to clinical pathology (eg, cognitive impairments, psychotic symptoms) reported to be associated with long-term methamphetamine use. Although interpretations from both studies are tempting, their generality or clinical importance remain uncertain owing to a few important limitations. For example, both studies evaluated only a small number of participants. More importantly, however, it is unclear whether an approximately $20 \%$ difference in DAT density, as measure with conventional PET-imaging techniques, is within the normal range of human variability or whether this difference is associated with alterations in cognitive functioning. In other words, the clinical relevance of such findings is impossible to determine because cognitive functioning was not assessed. The point here is not to give precedence to behavioral over neuroimaging data, but to emphasize the need to include relevant functional outcomes that allow us to understand the consequences of the neural activity. Without behavioral measures, we may be enticed to make unwarranted speculations about the neural basis of behavior.

Addressing some of the shortcomings of previous investigations, Johanson and co-workers (2006) conducted a PET study that did include cognitive assessment. This group of researchers used an extensive cognitive battery to compare functioning of abstinent methamphetamine abusers $(N=16)$ with control participants $(N=18)$. They used $\left[{ }^{11} \mathrm{C}\right]$ methylphenidate and $\left[{ }^{11} \mathrm{C}\right]$ dihydrotetrabenazine to determine striatal levels of DAT and VMAT-2, respectively. They found that although striatal DAT and VMAT-2 binding potentials were $10-16 \%$ lower in methamphetamine users, cognitive performance on the majority of tasks was not significantly different. Neither neuroimaging nor cognitive data were correlated with methamphetamine abstinence duration. Methamphetamine users did, however, perform more poorly than controls on tasks that tapped the domains of sustained attention and immediate and longterm memory. Importantly, though, the methamphetamine users' performance remained within the normal range for their age and educational group. The authors appropriately concluded that while their imaging data showing differences between abstinent long-term methamphetamine users and controls were consistent with previous investigations (eg, McCann et al, 1998; Volkow et al, 2001b; see also, Boileau et al, 2008), the functional significance of these differences might be limited because methamphetamine users' performance on most tests was equal to controls and no relationship between the imaging data and cognitive deficits was observed. While the number of participants studied was larger than that examined in most previous PET studies, it is possible that greater numbers are necessary to observe clinically meaningful cognitive impairments.

Another point relevant to the above discussion is that the conclusions drawn by Johanson et al (2006) appear to conflict with those of a similar subsequent study. McCann et al (2008) found that methamphetamine users exhibited significantly lower DAT binding (13-23\%), poorer performance on a minority of cognitive tasks (tasks measuring attention and long-term memory), and no relationship between duration of abstinence and neuroimaging results or cognitive performance. These data are in agreement with the findings of Johanson et al (2006). Despite this, McCann et al (2008) interpreted their data as evidence demonstrating a connection between recreational methamphetamine use and pathology. Given that the data alone do not contradict each other, the apparent incongruence in conclusions drawn centers on the interpretations of the cognitive findings obtained.

Recognizing this distinction between results and interpretation of results, we can now highlight a prevalent concern throughout the body of scientific literature investigating methamphetamine-associated effects on human cognition. If we limit our focus to cognitive performance - the behavior of interest here-we can see that control subjects outperformed methamphetamine users on a few tasks in both studies. The clinical implications of such differences, however, are nearly impossible to determine without knowledge of the expected performance for a particular group, taking into account group members' age and education (ie, normative data). While Johanson et al, interpreted their cognitive findings within the context of these important constraints, McCann et al provided no such comparative information, which makes it difficult to evaluate the clinical import of neurocognitive differences. When we compared the cognitive performance mean scores of the methamphetamine users in the McCann et al study, with normative scores, none of the former were outside of the normal range. Even scores obtained on measures that showed statistically significant differences between methamphetamine users and controls were within the normal range. This observation not only calls into question the clinical significance of the cognitive differences observed in the McCann et al study, but it also underscores the importance of interpreting cognitive findings within the range of performance for age- and education-matched controls. Otherwise, we run the risk of stigmatizing individuals, which could have debilitating consequences.

The preceding point is worth elaborating. The literature on methamphetamine use is focused on 'impairment,' and seems to conflate two different meanings of this term. One meaning is captured by the canonical situation in which one group of participants performs statistically significantly less well on a task than does a control group. Although there is a statistically significant difference, its clinical relevance, or everyday import, is rarely specified. A second meaning of 'impairment' is that of a substantial loss of function, a dysfunction, in which performance may even fall outside of normal range and bears clinical significance. (The two meanings probably represent end points on a continuum of meanings of 'impairment' that appears in the general literature on group differences.) The problem in the literature on methamphetamine use is that in many studies the results support only the first or difference interpretation, but the results are discussed in terms of the 'dysfunctional' interpretation. In essence, the English word 'impairment' (or 'deficit') is ambiguous, and researchers in this field often switch meanings in moving from actual findings to discussion of the implications of these findings.

PET studies investigating brain metabolism of abstinent methamphetamine users. Other researchers have used PET imaging to evaluate brain glucose metabolism in abstinent methamphetamine users while they perform some cognitive 
task. Because all neurons use blood glucose for their energy, this strategy provides an indirect measure of neuronal activity. Table 2 summarizes the studies that have used this approach to compare regional brain activity of methamphetamine users with that of control participants. The majority of these studies have found some differences between the groups. In one series of studies, London and co-workers used $\left[{ }^{18} \mathrm{~F}\right]$ flurodeoxyglucose (FDG) as the ligand to evaluate recently abstinent methamphetamine abusers and control participants while performing a 30-min auditory continuous-performance or sustained attention task. These investigators reported that the two groups did not differ on task performance, but did differ on measures of relative regional glucose metabolism: methamphetamine abusers exhibited lower metabolism in the anterior cingulate and insula and higher metabolism in other areas, including the amygdala and ventral striatum (London et al, 2004). These findings provide additional evidence that brain differences observed between methamphetamine abusers and controls may not necessarily reflect cognitive impairments. However, the investigators did find that the methamphetamine users scored higher on Beck Depression Inventory and State-Trait Inventory scales than the controls. Even though these inventories alone are not used diagnostically, this led them to conclude that their findings identify 'brain dysfunction that may underlie affective deficits in methamphetamine abusers... .'

There are at least two concerns associated with this conclusion. First, it is impossible to state with any degree of certainty that increased or decreased relative regional glucose metabolism in a particular brain region is 'dysfunctional,' especially without knowledge of the normal range of functioning. Again, the results show that there is a difference, but the interpretation goes beyond that to posit a dysfunction. This point is even clearer when it comes to the finding that methamphetamine users had higher Beck Depression Inventory and State-Trait Anxiety Inventory scores than the control group. The mean scores for methamphetamine users on these inventories did not approach the clinically significant range, for example, methamphetamine users did not approach the threshold for clinical depression. Here, we have a clear case of difference that does not meet an accepted standard of clinical dysfunction. This case illustrates the propensity to interpret any brain difference as pathology, even when there are no differences on functional outcome measures (the cognitive measure) or there are differences (the affective scales), but the clinical importance of the differences is unclear.

In subsequent studies, differences in cognitive functioning, as well as brain glucose metabolism, have been noted (eg, London et al, 2005; Kim et al, 2005). In one recent study, Kim et al (2009) compared abstinent Korean methamphetamine abusers $(N=24)$ with control participants $(N=21)$ and reported that methamphetamine users had significantly lower inferior frontal cortex resting activity. Further, the methamphetamine users performed markedly worse on the Wisconsin card sorting task (WCST), which is a measure of set-shifting (or cognitive flexibility), attention, and inhibition. However, performance on the WCST was not correlated with brain activity. Hence, the researchers' conclusion that their findings provide evidence of 'frontal abnormalities' and 'executive dysfunction' in methamphetamine abusers is somewhat misleading. In addition, there is the usual caveat that it is critically important to interpret cognitive functioning data within the constraints of the larger normative data set. Otherwise, it is difficult to make definitive statements about the functional significance of the data. Kim et al (2009) did not report this type of comparison in their study, perhaps, in part, because there are no published Korean norms for the WCST. For these reasons, speculations about 'frontal executive dysfunction' in the methamphetamine users studied seem unwarranted.

The Kim et al (2009) study raises two other issues. First, it is inappropriate to conclude that individuals who perform more poorly than controls on the WCST have 'executive deficits' (which include deficits in attention, inhibition, and working memory). Performance on multiple tasks, which assess the same domains, should be evaluated before making such claims because individual tasks may tap slightly different components of the domain of interest (ie, the measures must be functionally validated in advance). Thus, there is a lack of construct validity here, which to some extent is true of other studies that include only a single task to measure a cognitive domain. Second, there may be many reasons for poor relative task performance in Kim et al (2009). One potential explanation for the findings could be related to educational level. Control participants had a significantly higher level of education than methamphetamine users, and individuals with more education have been demonstrated to outperform those with less education on the WCST (Boone et al, 1993; Heaton et al, 1993).

In general, studies using PET imaging have produced inconsistent results. Some data demonstrate DAT binding potential, DA receptor availability, and brain glucose metabolism differences between abstinent methamphetamine users and control participants. Several researchers have found lower striatal DAT and DA $\mathrm{D}_{2}$ receptor levels in long-term methamphetamine users, although there is considerable overlap between methamphetamine users and control participants. In addition, some reports suggest extended abstinence increases methamphetamine users' DAT levels (Volkow et al, 2001d), but others failed to observe similar findings (McCann et al, 2008). Despite this, duration of abstinence appears to have little effect on cognitive performance (eg, Volkow et al, 2001d; Johanson et al, 2006; McCann et al, 2008). While findings from brain glucose metabolism studies indicate that methamphetamine users, in comparison with control participants, display a different pattern of activity in some regions, many of these differences have not been replicated by independent groups of researchers. For example, Volkow et al (2001a) found that methamphetamine users had higher absolute regional cerebral glucose metabolism, whereas London et al (2004) reported that methamphetamine users and controls did not differ on this measure. As usual, evidence of the impact of the observed brain differences on cognitive functioning appears to be limited. In the few studies that have included a comprehensive cognitive battery, methamphetamine users perform similarly to controls on the vast majority of tasks, and even on tasks in which significant group differences were noted, methamphetamine-using individuals' performance was within the normative range for their age- and 
education-matched cohort (eg, Johanson et al, 2006). Moreover, in the majority of studies, methamphetamine users reported extensive use of other psychoactive drugs, while comparison groups reported only limited drug use (see Table 2). This makes it extremely difficult to disentangle methamphetamine-related effects on cognitive functioning from those of other drugs. Despite these important caveats, the PET-imaging literature is replete with a general tendency to characterize any brain and/or cognitive performance differences as dysfunctions unique to methamphetamine users.

MRI studies investigating brain structure sizes of abstinent methamphetamine users. As seen in Table 3, a growing number of investigators have used magnetic resonance imaging (MRI) procedures combined with cognitive testing to understand the impact of long-term recreational methamphetamine use on cognitive functioning. One advantage of MRI, relative to PET, is that MRI provides high-resolution images of brain structure sizes and thickness. The use of MRI is also less invasive; unlike PET, it does not require the injection of radioactive compounds. In one of the most highly cited scientific articles in this area of research (also featured in The New York Times, 20 July 2004: see Blakeslee (2004)), Thompson and co-workers (2004) used MRI to compare brain structure volume and cognitive performance of methamphetamine-dependent individuals $(N=22)$ with control participants $(N=21)$. They found that, relative to controls, methamphetamine users had lower gray matter volumes in the right cingulate gyrus $(-11.3 \%)$ and hippocampal region $(-7.8 \%)$, although no differences were observed in total cerebral or total gray matter volumes. In contrast, total white matter volumes $(+7.0 \%)$ and right lateral ventricles $(+25.2 \%)$ were greater in the methamphetamine users. The four cognitive tasks administered involved only long-term memory (ie, wordand picture-recall and word- and picture-recognition), and only performance on the word-recall task was positively correlated with hippocampal volume. Further, there was no data comparing methamphetamine users with controls on any memory task. Yet, the investigators concluded that '...chronic methamphetamine abuse causes a selective pattern of cerebral deterioration that contributes to impaired memory performance.'

This interpretation clearly goes far beyond the data. First, brain images were collected at only one time point for both groups of participants. This makes it virtually impossible to determine whether methamphetamine caused 'cerebral deterioration,' as pre-existing differences between the two groups of participants cannot be ruled out. Furthermore, the functional significance of the structural differences is in doubt. Based on the limited cognitive results presented, it appears that the brain structural size differences were not predictive of overall memory performance. The only statistically significant cognitive finding was a correlation of hippocampal volume and performance on one of the four tasks. This finding is the basis for the claim that methamphetamine users had memory impairments, because the hippocampus is known to play a role in some long-term memory; however, other neural areas are also involved in mediating long-term memory (eg, overlying temporal neocortex), and one of them could have been the critical mediator of performance in this study. Another pertinent issue was that control participants had markedly higher levels of schooling than methamphetamine users (15.2 vs 12.8 years, respectively); it is well established that educational level modulates long-term memory (Mitrushina et al, 2005). In light of these considerations, it is somewhat disconcerting that the results from the study were construed as findings of pathology rather than preliminary evidence of group differences that appear to have limited or doubtful functional significance.

Another line of research aimed at understanding the impact of methamphetamine use on cognition and brain functioning is the use of perfusion MRI to determine regional cerebral blood flow. Chang and co-workers (2002) evaluated 20 abstinent methamphetamine abusers and 20 control participants with this procedure and assessed their cognitive performance using an extensive neuropsychological test battery. Although the groups did not differ on global measures of brain volumes or cerebrospinal fluid, methamphetamine users were reported to have lower relative regional cerebral blood flow bilaterally in the putamen/insular cortices $(\sim-11 \%)$ and in the right lateral parietal cortex $(-11 \%)$. In contrast, the methamphetamine users were found to have greater relative regional cerebral blood flow in the left temporoparietal white matter $(+13 \%)$, the left occipital brain region $(+10 \%)$, and the right posterior parietal region $(+24 \%)$. When methamphetamine users' cognitive performance was compared with age- and education-matched normative data, their performance was within the normal range for all tasks, including those assessing attention and long-term memory, as well as those reflecting psychomotor speed, fine motor speed (Grooved pegboard), and gross motor functioning (Timed gait). On an additional test battery (customized California Computerized Assessment Package: CalCAP), methamphetamine users, relative to controls, exhibited slower reaction times on some tasks, although task accuracy was overwhelmingly similar. As a result of these findings, Chang et al (2002) concluded that methamphetamine users 'not only had cerebral perfusion abnormalities, but also demonstrated cognitive deficits.' They further noted that the imaging technique used appeared to be a more sensitive measure for detecting brain function abnormalities.

Such conclusions are puzzling. The conclusion that methamphetamine users had cognitive deficits was based primarily on the reaction time, not the accuracy, of the results obtained during some CalCAP tasks, which suggest a motor slowing, rather than cognitive deficits. Furthermore, there are problems in interpreting differences. As noted earlier, if one wants to determine whether an individual's performance is normal, a fundamental requirement is that the performance has to be compared against a normative score, taking into consideration the individual's age and level of education. To avoid misinterpretations (such as overpathologizing), normative data are imperative because they allow us to take into account the relative contribution of age and education in terms of the individual's score and adjust the score accordingly. With regard to CalCAP performance in the study by Chang et al (2002), this was not done, and the range of normative scores was not presented. Similarly, the brain-imaging results obtained in 
Table 3 MRI Studies

\begin{tabular}{|c|c|c|c|c|c|}
\hline Investigators & Domain tested & Participants & Period of abstinence & Cognitive and brain findings & Caveats \\
\hline \multicolumn{6}{|l|}{ MRI } \\
\hline Chang et al (2005) & $\begin{array}{l}\text { Attention/psychomotor function (TMT-A, } \\
\text { Grooved pegboard, Timed gait task, Stroop, } \\
\text { CalCAP); Visuospatial perception (DSST); } \\
\text { Learning/memory (AVLT, Rey-Osterrieth } \\
\text { complex figure test); Working memory } \\
\text { (CalCAP); Response inhibition (Stroop, } \\
\text { CalCAP); Set-shifting/executive function (TMT-B, } \\
\text { New adult reading test) }\end{array}$ & $\begin{array}{l}\text { MA users met the DSM-IV criteria for } \\
\text { MA dependence } \\
\text { Cognitive testing: MA users: } N=44 \\
\text { Controls: } N=28 \\
\text { Imaging: } M A \text { users: } N=50 \\
\text { Controls: } N=50\end{array}$ & $\begin{array}{l}\text { Mean } 4.0 \pm 6.2 \text { months } \\
\text { (required I-week minimum) }\end{array}$ & $\begin{array}{l}\text { Cognitive: } \leftrightarrow \text { No differences on cognitive tests } \\
\text { observed after co-varying for education } \\
\text { Brain: } \leftrightarrow \text { Whole brain volumes } \\
\uparrow \text { Globus pallidus volumes } \\
\uparrow \text { Putamen volumes }\end{array}$ & $\begin{array}{l}\text { Controls had higher levels of education } \\
\text { The influence of drug use other than MA not } \\
\text { controlled }\end{array}$ \\
\hline Kim et al (2006) & $\begin{array}{l}\text { Attention/psychomotor function (TMT-A); } \\
\text { Response inhibition (Stroop); Set-shifting/ } \\
\text { executive function (TMT-B, WCST) }\end{array}$ & $\begin{array}{l}\text { MA users met the DSM-IV criteria for } \\
\text { MA dependence } \\
\text { Short term ( }<6 \text { months): MA users: } \\
N=11 \\
\text { Long term ( }>6 \text { months): MA users: } \\
N=18 \\
\text { Controls: } N=20\end{array}$ & $\begin{array}{l}\text { Long-term: mean } 30.6 \pm 39.2 \text { months } \\
\text { Short-term: mean } 2.6 \pm 1.6 \text { months }\end{array}$ & $\begin{array}{l}\text { Cognitive: } \downarrow \text { Set-shifting/executive function } \\
\text { (WCST): short-term }>\text { long-term }>\text { controls } \\
\leftrightarrow \text { Attention/psychomotor function } \\
\leftrightarrow \text { Response inhibition } \\
\leftrightarrow \text { Set-shifting/executive function } \\
\text { Brain: } \downarrow \text { GM density in } R \text {. middle frontal gyrus } \\
\text { (short-term abstinent < long-term }<\text { controls) } \\
\leftrightarrow \text { WM density }\end{array}$ & $\begin{array}{l}\text { Controls had higher levels of education } \\
\text { Cognitive data not compared against normative } \\
\text { data set. Thus, the clinical importance of findings } \\
\text { could not be determined } \\
\text { The influence of drug use other than MA not } \\
\text { controlled } \\
\text { Small number of participants studied }\end{array}$ \\
\hline Thompson et al (2004) & $\begin{array}{l}\text { Immediate and delayed memory (word-recall } \\
\text { and recognition; picture-recall and recognition); } \\
\text { Attention/psychomotor function (TMT-A); } \\
\text { Visuospatial perception (DSST) }\end{array}$ & $\begin{array}{l}\text { MA users met the DSM-IV criteria for } \\
\text { MA dependence: } N=22 \\
\text { Controls: } N=21\end{array}$ & $\begin{array}{l}\text { Participants reported having used MA a } \\
\text { majority of the past } 30 \text { days }\end{array}$ & $\begin{array}{l}\text { Cognitive: Comparisons between the two } \\
\text { groups not reported, but a significant } \\
\text { correlation between hippocampal volume and } \\
\text { performance on the word-recall task was noted } \\
\text { for all participants } \\
\text { Brain: } \downarrow \text { GM in the cingulate cortex } \\
\downarrow G M \text { in the limbic cortex } \\
\downarrow G M \text { in the paralimbic cortex } \\
\downarrow \text { Hippocampal volumes } \\
\uparrow \text { WM hypertrophy } \\
\leftrightarrow \text { Total cerebral volume } \\
\leftrightarrow \text { Total GM }\end{array}$ & $\begin{array}{l}\text { Controls had higher levels of education } \\
\text { Clinical importance and relationship between } \\
\text { cognitive functioning and brain activity could not be } \\
\text { determined because limited cognitive data not } \\
\text { reported and cognitive data not compared against } \\
\text { normative data set } \\
\text { The influence of drug use other than MA not } \\
\text { controlled } \\
\text { Small number of participants studied }\end{array}$ \\
\hline \multicolumn{6}{|l|}{ pMRI } \\
\hline Chang et al (2002) & $\begin{array}{l}\text { Attention/psychomotor function (TMT-A, } \\
\text { Grooved pegboard, Timed gait task, Stroop, } \\
\text { CalCAP); Visuospatial perception (DSST); } \\
\text { Learning/memory (AVLT); Working memony } \\
\text { (CalCAP); Response inhibition (Stroop, } \\
\text { CalCAP); Set-shifting/executive function (TMT-B, } \\
\text { New adult reading test) }\end{array}$ & $\begin{array}{l}\text { MA users met the DSM-IV criteria for } \\
\text { MA dependence: } N=20 \\
\text { Controls: } N=20\end{array}$ & Mean $8.0 \pm 2.2$ months & $\begin{array}{l}\text { Cognitive: } \leftrightarrow \text { Regarding the standard cognitive } \\
\text { that was compared against a normative data } \\
\text { set, no differences on task accuracy noted for } \\
\text { any tests } \\
\text { CalcAP Performance: } \\
\downarrow \text { Reaction time on several tasks } \\
\downarrow \text { Accuracy on I-increment and 2-back } \\
\text { working memory tasks } \\
\text { Brain } \downarrow \text { rCBF in bilateral putamen } \\
\downarrow \text { rCBF in bilateral insula } \\
\downarrow \text { rCBF in right lateral parietal } \\
\uparrow r C B F \text { in left temporoparietal WM } \mathrm{WCBF} \text { in } \\
\text { left occipital } \\
\uparrow \text { rCBF in right posterior parietal }\end{array}$ & $\begin{array}{l}\text { Clinical importance and relationship between } \\
\text { cognitive functioning and brain activity could not be } \\
\text { determined because CalCAP data was not } \\
\text { compared against normative data set } \\
\text { The influence of drug use other than MA not } \\
\text { controlled } \\
\text { Small number of participants studied }\end{array}$ \\
\hline \multicolumn{6}{|l|}{ DTI } \\
\hline Chung et al (2007) & Set-shifting/executive function (WCST) & $\begin{array}{l}\text { MA users met the DSM-IV criteria for } \\
\text { MA dependence: } N=32 \\
\text { Controls: } N=30\end{array}$ & $\begin{array}{l}\text { Males: mean } 24.3 \pm 37.5 \text { months } \\
\text { Females: mean } 43.1 \pm 65.9 \text { months }\end{array}$ & $\begin{array}{l}\text { Cognitive: } \downarrow \text { Set-shifting/executive function } \\
\text { (WCST) } \\
\text { Brain: } \downarrow F A \text { values in bilateral frontal WM } \\
\text { at AC-PC plane } \\
\downarrow \text { FA values in right frontal WM at } 5 \mathrm{~mm} \text { above } \\
\text { AC-PC plane }\end{array}$ & $\begin{array}{l}\text { Controls had higher levels of education } \\
\text { Only one cognitive measure included and it was not } \\
\text { compared against normative data set, which makes } \\
\text { it difficult to determine the clinical importance of } \\
\text { findings } \\
\text { The influence of drug use other than MA not } \\
\text { controlled }\end{array}$ \\
\hline
\end{tabular}


Table 3 Continued

\begin{tabular}{|c|c|c|c|c|c|}
\hline Investigators & Domain tested & Participants & Period of abstinence & Cognitive and brain findings & Caveats \\
\hline Salo et al (2009a) & Attention/response inhibition (Stroop) & $\begin{array}{l}\text { MA users met the DSM-IV criteria for } \\
\text { MA dependence: } N=37 \\
\text { Controls: } N=17\end{array}$ & $\begin{array}{l}\text { Mean } 20.98 \pm 31.9 \text { months } \\
\text { (required 3-week minimum) }\end{array}$ & $\begin{array}{l}\text { Cognitive: } \downarrow \text { Response inhibition } \\
\text { Brain: } \leftrightarrow F A \text {, ADC, or diffusion along direction } \\
\text { of axonal fiber in genu or splenium of CC }\end{array}$ & $\begin{array}{l}\text { Controls had higher levels of education and IQ } \\
\text { (NART) } \\
\text { Only one cognitive measure included and it was not } \\
\text { compared against normative data set, which makes } \\
\text { it difficult to determine the clinical importance of } \\
\text { findings } \\
\text { The influence of drug use other than MA not } \\
\text { controlled }\end{array}$ \\
\hline \multicolumn{6}{|l|}{ FMRI } \\
\hline Hoffman et al (2008) & Impulsivity (Delayed discounting task) & $\begin{array}{l}\text { MA users met the DSM-IV criteria for } \\
\text { MA dependence: } N=19 \\
\text { Controls: } N=17\end{array}$ & Mean $48 \pm 17$ days & $\begin{array}{l}\text { Cognitive: } \downarrow \text { MA users preferred smaller } \\
\text { immediate reward, ie, discounted more steeply } \\
\text { Brain: } \downarrow \text { Bilateral precuneus } \\
\downarrow \text { Right caudate nucleus } \\
\downarrow \text { ACC } \\
\downarrow \text { DLPFC }\end{array}$ & $\begin{array}{l}\text { Only one cognitive measure included and there are } \\
\text { no normative data set for which the data can be } \\
\text { compared, which makes it difficult to determine the } \\
\text { clinical importance of findings } \\
\text { The influence of drug use other than MA not } \\
\text { controlled } \\
\text { MA-dependent participants tested } \\
\text { on an in-patient basis, while controls } \\
\text { tested on an outpatient basis } \\
\text { Small number of participants studied }\end{array}$ \\
\hline Leland et al (2008) & Response inhibition (Go/No-go task) & $\begin{array}{l}\text { MA users met the DSM-IV criteria for } \\
\text { MA dependence: } N=19 \\
\text { Controls: } N=19\end{array}$ & Mean $33.9 \pm 5.9$ days & $\begin{array}{l}\text { Cognitive: } \leftrightarrow \text { Response inhibition } \\
\text { Brain: } \uparrow \text { Cue-related activation in two ACC } \\
\text { ROIs }\end{array}$ & $\begin{array}{l}\text { Only one cognitive measure included } \\
\text { The influence of drug use other than MA not } \\
\text { controlled } \\
\text { Small number of participants studied }\end{array}$ \\
\hline Monterosso et al (2007) & Impulsivity (Delayed discounting task) & $\begin{array}{l}\text { MA users met the DSM-IV criteria for } \\
\text { MA dependence: } N=12 \\
\text { Controls: } N=17\end{array}$ & Range $5-7$ days & $\begin{array}{l}\text { Cognitive: } \downarrow \text { MA users preferred smaller } \\
\text { immediate reward, ie, discounted more steeply } \\
\text { Brain: } \downarrow \text { Differences in activation between hard } \\
\text { and easy choices in left DLPFC and intraparietal } \\
\text { sulcus }\end{array}$ & $\begin{array}{l}\text { Participant educational information not reported } \\
\text { Only one cognitive measure included and there are } \\
\text { no normative data set for which the data can be } \\
\text { compared, which makes it difficult to determine the } \\
\text { clinical importance of findings } \\
\text { No correlation between delayed discounting and } \\
\text { brain data observed } \\
\text { The influence of drug use other than MA not } \\
\text { controlled } \\
\text { Small number of participants studied }\end{array}$ \\
\hline Paulus et al (2002) & Decision-making (Two-choice prediction task) & $\begin{array}{l}\text { MA users met the DSM-IV criteria for } \\
\text { stimulant dependence: } N=10 \\
\text { Controls: } N=10\end{array}$ & Mean $22.4 \pm 3.5$ days & $\begin{array}{l}\text { Cognitive: MA users more influenced by } \\
\text { immediately preceding outcome } \\
\text { Brain: } \downarrow \text { Activation in DLPFC during } \\
\text { 2-choice prediction task compared to } \\
\text { 2-choice response task } \\
\downarrow \text { No activation in ventromedial cortex in } \\
\text { 2-choice prediction task compared to } \\
\text { 2-choice response task }\end{array}$ & $\begin{array}{l}\text { Only one cognitive measure included and there are } \\
\text { no normative data set for which the data can be } \\
\text { compared, which makes it difficult to determine the } \\
\text { clinical importance of findings } \\
\text { The influence of drug use other than MA not } \\
\text { controlled } \\
\text { Small number of participants studied }\end{array}$ \\
\hline Paulus et al (2003) & Same as above & $\begin{array}{l}\text { MA users met the DSM-IV criteria for } \\
\text { stimulant dependence: } N=14 \\
\text { Controls: } N=14\end{array}$ & Mean $25.0 \pm 2.7$ days & $\begin{array}{l}\text { Cognitive: } \leftrightarrow \text { Decision-making (but greater } \\
\text { win-stay/lose-shift consistent responses) } \\
\text { Brain: } \downarrow \text { Task-related activation in ACC, } \\
\text { DLPFC, orbitofrontal, and parietal cortex }\end{array}$ & $\begin{array}{l}\text { Controls had higher levels of education } \\
\text { Only one connitive measure included and there are } \\
\text { no normative data set for which the data can be } \\
\text { compared, which makes it difficult to determine the } \\
\text { clinical importance of findings } \\
\text { The influence of drug use other than MA not } \\
\text { controlled } \\
\text { Small number of participants studied }\end{array}$ \\
\hline
\end{tabular}


methamphetamine users were not compared with normative data, which again limit speculations about abnormalities. Yet, it was suggested that the modest observed brain-imaging differences provided a more sensitive measure of brain function abnormalities. This interpretation seems particularly inappropriate in light of the fact that methamphetamine users' overall cognitive performance (a crucial measure of brain functioning) was nearly identical to that of the control group.

A different MRI technique used to study methamphetamine users is diffusion tensor imaging (DTI), which can be used to assess brain white matter integrity and to localize focal lesions respective to major white matter tracts. The most frequently used dependent measures derived from DTI scans are: (1) fractional anisotropy, a measure of the directionality of diffusion; and (2) apparent diffusion coefficient, a measure of the magnitude of the diffusion. Using this method, Salo et al (2009a) compared brain activity during Stroop task performance in methamphetamine abusers $(N=37)$ and control participants $(N=17)$. They found that the groups did not differ on any of the quantitative parameters derived from DTI or the number of errors made on the Stroop task. The only statistically significant difference obtained was that methamphetamine users performed more slowly on the Stroop task than the controls. However, this effect was no longer significant when participants' National Adult Reading Test scores were included as a covariate in the analysis. Longer response times on the Stroop task were significantly correlated with lower fractional anisotropy values in the genu of corpus callosum, but there was no interaction with group, that is, whether or not the participant was a methamphetamine user had no effect on the correlation. Similarly, duration of methamphetamine use or length of methamphetamine abstinence were not significantly correlated with any of the DTI measures. Despite the study's limitations (see Table 3) and modest findings, it was concluded that 'disruption of neural function in the rostral ACC (anterior cingulate cortex) and adjacent WM (white matter) produces a disruption in the pathways that are involved in behavioral regulation' (Salo et al, 2009a). For many of the same aforementioned concerns, a more tempered interpretation of the collected data would appear to be in order.

Functional MRI (fMRI) has also been used to study longterm methamphetamine abusers. Functional MRI reflects brain blood flow and other factors, and its signal increases when neurons become more active. In this way, fMRI can provide an indirect measure of neural activity. For example, Salo and co-workers (2009b) employed fMRI to image brain activity of methamphetamine users $(N=12)$ and control participants $(N=16)$ while they completed a Stroop task. Although no group differences were observed on task accuracy, the methamphetamine users, unlike the controls, did not show trial-to-trial reaction time improvements. This effect corresponded with reduced activation in the right prefrontal cortex of methamphetamine users, which led the investigators to conclude that their 'data provide preliminary evidence that methamphetamine abuse is associated with deficits in behavioral regulation associated with abnormal prefrontal cortex activation... .' Again, this seems to be an overinterpretation of modest results. As noted 
before, meaningful group differences should be observed on multiple measures of a particular cognitive domain (attention and inhibition in the case of Stroop) before making assertions about deficits in this domain. Also, again the only difference obtained in this study was that methamphetamine users performed the task more slowly than their nondrug-using counterparts, although their accuracy rates were equal, which is consistent with response slowing rather than a cognitive deficit. Similarly, prefrontal cortex activation in the methamphetamine users was said to be 'abnormal,' but the range of normal human activation was not presented or discussed.

Overall, MRI observations are consistent with data from PET studies in that several brain-imaging differences have been noted between methamphetamine users and controls, but few of these findings have been independently replicated. Unlike PET studies, where the focus, for the most part, has been appropriately limited to monoaminerich brain areas, fMRI studies do not appear to have a consistent rationale for targeting regions of interest. With regard to cognitive functioning, few statistically significant differences have been observed between methamphetamine users and control participants. Even when differences were found, it is difficult to contextualize their functional significance because frequently they are not correlated with methamphetamine-use indicators (eg, duration of abstinence, duration of methamphetamine abuse, frequency of methamphetamine use) and they are often not compared against normative scores.

Comprehensive neuropsychological testing of abstinent methamphetamine abusers. A major weakness associated with much of the neuroimaging literature is that most studies have included limited cognitive testing - only one or two cognitive domains are assessed, and each by only a simple task. This makes it extremely difficult to draw conclusions about the clinical significance of the data collected. To address this concern, as is shown in Table 4, some researchers have focused their efforts exclusively on assessing cognitive functioning of methamphetamine users in comparisons with control participants. Typically, abstinent methamphetamine abusers and controls complete a comprehensive battery of neuropsychological testing over the course of several hours, and the results are compared to determine whether or not the cognitive performance of the methamphetamine groups is normal. Of course, as noted above, normality is a relative concept that should be determined by comparing performance of a targeted group with scores from a normative data set. Although this is a fundamental requirement of neuropsychological testing, it has been frequently ignored in the methamphetamine/ cognition literature.

For example, Simon et al (2002) compared cognitive functioning of 40 methamphetamine abusers with 40 control participants using a standard neuropsychological test battery, which assessed functioning in several areas including attention, working memory, inhibition, long-term memory, and perceptual speed. They found that, compared with controls, methamphetamine-abusing participants performed significantly worse on tests measuring: (1) inhibition (Stroop, WCST); (2) attention and cognitive flexibility
(WCST); and (3) psychomotor function and speed. As a result of these statistical differences between the groups, the authors concluded that methamphetamine users were impaired in multiple cognitive domains. Recall our earlier discussion of the ambiguity of 'impairment' and our emphasis on the importance of comparing performance scores of methamphetamine users against normative scores before drawing inferences about the clinical significance of a difference on cognitive tests. The data from the Simon et al, study were not interpreted within these confines. However, when we compared the mean neuropsychological scores of the methamphetamine abusers in the Simon et al study against published normative scores, none of methamphetamine users' scores fell outside of the normal range. Moreover, in a subsequent study, this same group of researchers failed to replicate any of their earlier statistically significant findings (Simon et al, 2010). Taken together, these observations further emphasize the importance of comparing performance against appropriate normative scores and they also demonstrate the value of having results replicated before making global statements about their clinical importance.

In a similar study (Kalechstein et al, 2003), the performance of abstinent methamphetamine-dependent individuals $(N=27)$ and control participants $(N=18)$ were compared across several cognitive domains including visuospatial perception, attention, inhibition, and response speed. An important strength of this study was that multiple tasks were assessed to determine functioning in a particular domain and published norms were taken into consideration when the study's findings were interpreted. In this way, it was possible to obtain convergent findings and their functional significance could be determined, which would increase confidence in the results and conclusions drawn. The researchers found that methamphetamine users and controls did not differ on most tests (eg, Stroop and Trail Making - both measures of attention and inhibition), but a greater proportion of the methamphetamine users were classified as being impaired within a particular domain because their individual score was at least 2 SDs below the mean for published normative data. On average, performance in at least one domain for approximately 7 of the 27 methamphetamine users met this stringent impairment criterion, whereas this number was 2 of 18 for the controls. This indicates that methamphetamine users were more than twice as likely as control participants to be classified as being impaired in at least one domain, which suggests that the scale of impairment in this sample was substantial. A closer examination of the data, however, suggests that this interpretation might be an overstatement. Sample size was relatively small, which increases the likelihood of data distortion. That is, when we look at the number of participants in each group that were determined to be impaired in the domain of working memory, for example, we see that only two control participants (11\%) and one methamphetamine user (4\%) met this criterion. Cognitive functioning fell within the normal range for the vast majority of study participants, including those dependent on methamphetamine. Also, while several other investigators have reported some differences in cognitive functioning between methamphetamine abusers and controls (eg, Hoffman et al, 2006; Han et al, 2008), the pattern of effects in the 
Table 4 Studies that have Included Neuropsychological Test Batteries Only

\begin{tabular}{|c|c|c|c|c|c|}
\hline Investigators & Domain tested & Participants & Period of abstinence & Cognitive findings & Caveats \\
\hline Henry et al (2009) & $\begin{array}{l}\text { Facial affect recognition (Pictures of Facial } \\
\text { Affect); Theory of mind (Mind in the Eyes } \\
\text { test); Executive functioning (Verbal fluency } \\
\text { test: FAS, Hayling Sentence Completion } \\
\text { Test); Learning/memory (AVLT) }\end{array}$ & $\begin{array}{l}\text { MA users met the DSM-IV criteria } \\
\text { for MA dependence (currently in } \\
\text { treatment): } N=20 \\
\text { Controls: } N=20 \\
\text { These are the same participants as } \\
\text { those in Rendell et al (2009) }\end{array}$ & Mean: $5.9 \pm 1.41$ months & $\begin{array}{l}\downarrow \text { Facial affect recognition } \\
\downarrow \text { Theory of mind } \\
\downarrow \text { Executive function } \\
\text { (I out of } 2 \text { tests) } \\
\downarrow \text { Learning/memory } \\
\leftrightarrow \text { Delayed recall }\end{array}$ & $\begin{array}{l}\text { Cognitive data not compared against normative } \\
\text { data set. Thus, the clinical importance of findings } \\
\text { could not be determined } \\
\text { The influence of drug use other than MA not } \\
\text { controlled } \\
\text { MA-dependent participants tested on an in- } \\
\text { patient basis, while controls tested on an } \\
\text { outpatient basis } \\
\text { Small number of participants studied }\end{array}$ \\
\hline Hoffman et al (2006) & $\begin{array}{l}\text { Visuospatial perception (Rey-Osterrieth } \\
\text { Complex Figure Test); Visual memory (Rey- } \\
\text { Osterrieth Complex Figure Test); } \\
\text { Immediate and long-term memory (Babcock } \\
\text { Story Recall); Learning/memory (AVLT); } \\
\text { Attention/psychomotor function (TMT-A, } \\
\text { Stroop, Grooved pegboard); Response } \\
\text { inhibition (Stroop); Set-shifting/executive } \\
\text { function (WCST, TMT-B); IQ (Shipley } \\
\text { Vocabulary) }\end{array}$ & $\begin{array}{l}\text { MA users met the DSM-IV criteria } \\
\text { for MA dependence (currently in } \\
\text { treatment): } N=41 \\
\text { Controls: } N=41\end{array}$ & Mean: $6.52 \pm 6.30$ months & $\begin{array}{l}\downarrow \text { Long-term memory } \\
\downarrow \text { Learning/memory } \\
\leftrightarrow \text { Visuospatial perception } \\
\leftrightarrow \text { Visual memory } \\
\leftrightarrow \text { Immediate memory } \\
\leftrightarrow \text { Attention/psychomotor function } \\
\leftrightarrow \text { Response inhibition } \\
\leftrightarrow \text { Set-shifting/executive function } \\
\leftrightarrow \text { IQ }\end{array}$ & $\begin{array}{l}\text { Controls had higher levels of education than MA } \\
\text { users } \\
\text { Cognitive data not compared against normative } \\
\text { data set. Thus, the clinical importance of findings } \\
\text { could not be determined } \\
\text { The influence of drug use other than MA not } \\
\text { controlled }\end{array}$ \\
\hline Kalechstein et al (2003) & $\begin{array}{l}\text { Attention/psychomotor function (TMT-A, } \\
\text { Symbol Digit Modalities Test, Stroop } \\
\text { Color); Visuospatial perception (Rey } \\
\text { Complex Figure Task-copy subtest); } \\
\text { Learning/memory (AVLT, WMS-III Logical } \\
\text { Memory; Rey Complex Figure } \\
\text { Test-delayed recall); Working memory } \\
\text { (Letter-Number Sequencing and Visual } \\
\text { Memory Span—-backwards subtests of } \\
\text { WMS-III); Response inhibition (Stroop); } \\
\text { Set-shifting/executive function (TMT-B, } \\
\text { Controlled Oral Word Association, } \\
\text { Ruff Figural Fluency Test) }\end{array}$ & $\begin{array}{l}\text { MA users met the DSM-IV criteria } \\
\text { for MA dependence: } N=27 \\
\text { Controls: } N=18\end{array}$ & $\begin{array}{l}\text { Current users (provided negative urine } \\
\text { sample on the day of testing) }\end{array}$ & $\begin{array}{l}\downarrow \text { Learning/memory ( } 3 \text { out of } 4 \text { tests) } \\
\downarrow \text { Verbal fluency } \\
\leftrightarrow \text { Attention/psychomotor function } \\
\text { (2 out of } 3 \text { tests) } \\
\leftrightarrow \text { Visuospatial perception } \\
\leftrightarrow \text { Working memory } \\
\leftrightarrow \text { Response inhibition } \\
\leftrightarrow \text { Set-shifting/executive function }\end{array}$ & $\begin{array}{l}\text { The influence of drug use other than MA not } \\
\text { controlled } \\
\text { Small number of participants studied }\end{array}$ \\
\hline Rendell et al (2009) & $\begin{array}{l}\text { Prospective memory (Virtual Week task); } \\
\text { Executive function (Verbal fluency test: FAS, } \\
\text { Hayling Sentence Completion Test); } \\
\text { Learning/memory (AVLT); Working memory } \\
\text { (Digits forward and backward) }\end{array}$ & $\begin{array}{l}\text { MA users met the DSM-IV criteria } \\
\text { for MA dependence (currently in } \\
\text { treatment): } N=20 \\
\text { Controls: } N=20 \\
\text { These are the same participants as } \\
\text { those in Henry et al (2009) }\end{array}$ & Mean $5.90 \pm 1.41$ months & $\begin{array}{l}\downarrow \text { Executive function } \\
\downarrow \text { Retrospective memory } \\
\downarrow \text { Prospective memory } \\
\downarrow \text { Working memory }\end{array}$ & $\begin{array}{l}\text { Cognitive data not compared against normative } \\
\text { data set. Thus, the clinical importance of findings } \\
\text { could not be determined } \\
\text { The influence of drug use other than MA not } \\
\text { controlled } \\
\text { MA-dependent participants tested on an in- } \\
\text { patient basis, while controls tested on an } \\
\text { outpatient basis } \\
\text { Small number of participants studied }\end{array}$ \\
\hline Simon et al (2000) & $\begin{array}{l}\text { Attention/psychomotor function (TMT-A, } \\
\text { Digit Symbol, Stroop); Immediate Memory } \\
\text { (word-recall and recognition; picture-recall } \\
\text { and recognition); Response inhibition } \\
\text { (Stroop); Set-shifting/executive function } \\
\text { (WCST, TMT-B, Verbal fluency test: FAS); } \\
\text { Working memory (Digits backward); IQ } \\
\text { (Shipley-Hartford Vocabulary and Abstract } \\
\text { Thinking) }\end{array}$ & $\begin{array}{l}\text { Current MA users: } N=65 \text {; no } \\
\text { information reported about } \\
\text { whether participants met the } \\
\text { DSM-IV criteria for an MA-use } \\
\text { disorder } \\
\text { Controls: } N=65\end{array}$ & $\begin{array}{l}\text { MA group was required to submit urine } \\
\text { positive for MA, but negative for all } \\
\text { other drugs on the day of testing }\end{array}$ & $\begin{array}{l}\downarrow \text { Immediate memory } \\
\text { (word- and picture-recall) } \\
\downarrow \text { Response inhibition } \\
\downarrow \text { IQ (I out of } 2 \text { tests: Abstract Thinking) } \\
\leftrightarrow \text { Immediate memory } \\
\text { (word and picture recognition) } \\
\leftrightarrow \text { Attention/psychomotor function } \\
\text { (2 out of } 3 \text { tests) } \\
\leftrightarrow \text { Set-shifting/executive function } \\
\text { (2 out of } 3 \text { tests) } \\
\leftrightarrow \text { Working memory }\end{array}$ & $\begin{array}{l}\text { Cognitive data not compared against normative } \\
\text { data set. Thus, the clinical importance of findings } \\
\text { could not be determined } \\
\text { The influence of drug use other than MA not } \\
\text { controlled } \\
\text { The influence of comorbid psychiatric disorders } \\
\text { such as ADHD and depression not controlled }\end{array}$ \\
\hline Simon et al (2002) & Same as above & $\begin{array}{l}\text { MA users met the DSM-IV criteria } \\
\text { for MA-use disorder: } N=40\end{array}$ & $\begin{array}{l}\text { MA group was required to submit urine } \\
\text { positive for MA, but negative for all }\end{array}$ & $\begin{array}{l}\downarrow \text { Attention/psychomotor function } \\
\text { ( } 2 \text { out of } 3 \text { tests) }\end{array}$ & $\begin{array}{l}\text { Cognitive data not compared against normative } \\
\text { data set. Thus, the clinical importance of findings }\end{array}$ \\
\hline
\end{tabular}




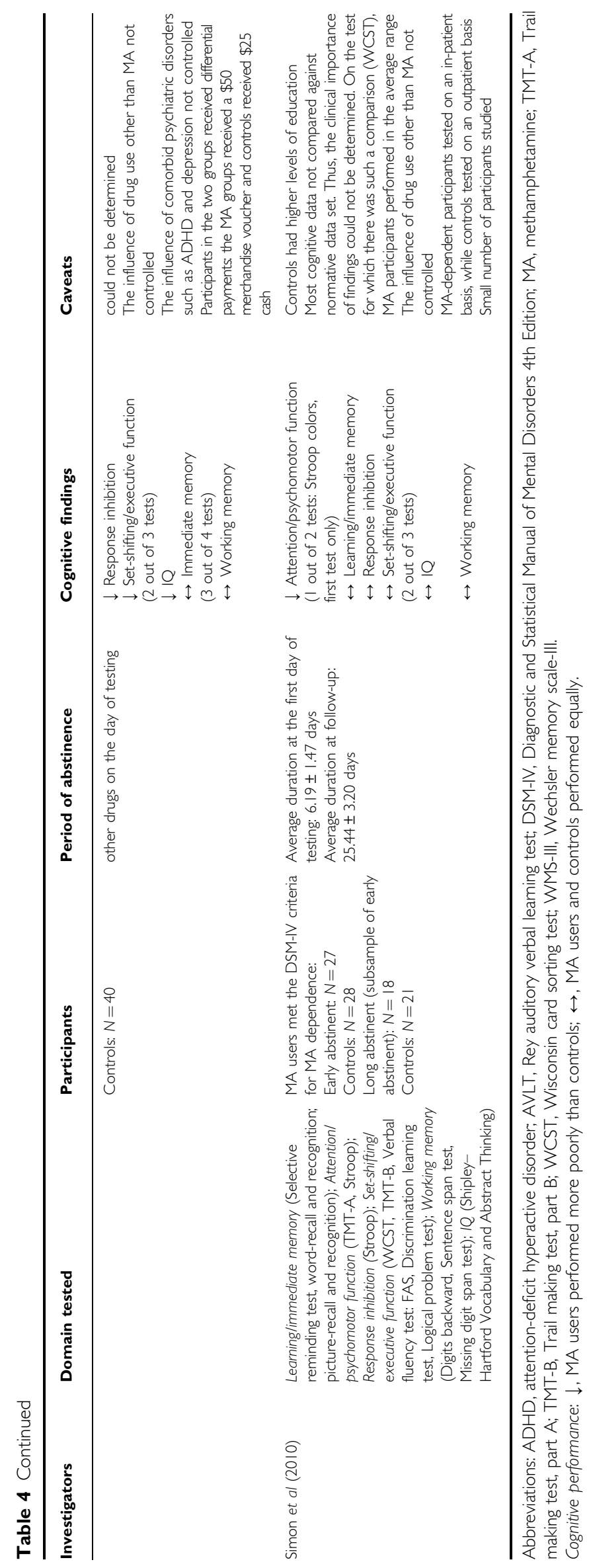

Kalechstein et al study (ie, in terms of clinical impairments) has yet to be replicated.

\section{CONCLUSIONS}

For more than a decade, research investigating the effects of methamphetamine use on human cognition has steadily increased. Diverse methodologies have been employed, including basic human laboratory studies, during which the acute effects of the drug on cognitive performance are assessed, and studies that combine brain imaging with neuropsychological evaluation. In general, the human laboratory data show that short-term, acute methamphetamine improves cognitive performance of both methamphetamine abusers and non-users in some domains, for example, visuospatial perception, sustained attention, and response speed, even when larger intranasal and intravenous doses are tested. Although enhanced cognitive performance was not observed in a few studies, it is important to note that methamphetamine-induced disruptive cognitive effects were not observed and therefore rarely reported. It is possible that if larger doses, administered repeatedly, had been studied, more negative effects on cognition would have been observed. This would not be surprising given that it is true with other psychoactive agents, including the legal recreational drugs, alcohol, and caffeine. Note, however, that most of the doses tested in the laboratory studies were within the range needed to induce euphoria in the natural setting. Nonetheless, a more comprehensive understanding of the acute effects of methamphetamine on cognition would require testing of larger doses.

With regard to brain-imaging studies, several researchers have reported neural differences between methamphetamine users and control participants. One consistent PET finding was lower striatal DAT density in methamphetamine users. Data from MRI and fMRI studies also revealed some differences in brain structure volume and integrity, and activity differences, between the groups, but there have been few replications of specific findings among studies. This is a crucial factor to consider when reading studies that purport to have identified regional differences between methamphetamine-using participants and controls because such findings might be spurious and unrelated to methamphetamine use. In addition, despite the fact that most neuroimaging studies included only limited cognitive measures and despite the fact that cognitive functioning of methamphetamine users generally fell within the normal range, researchers frequently interpreted any brain differences as indicative of cognitive pathologies caused by the abuse of methamphetamine.

Studies solely focused on assessing the cognitive functioning of abstinent methamphetamine users are plagued by similar interpretation concerns. That is, even though methamphetamine users' performance overwhelmingly remained within the normal range, most researchers concluded that they showed evidence of global cognitive impairments (the dysfunction meaning of 'impairment'). For example, the findings of Simon et al (2002) led them to warn: 
The national campaign against drugs should incorporate information about the cognitive deficits associated with methamphetamine... Law enforcement officers and treatment providers should be aware that impairments in memory and in the ability to manipulate information and change points of view (set) underlie comprehension ...methamphetamine abusers will not only have difficulty with inferences...but that they also may have comprehension deficits...the cognitive impairment associated with [methamphetamine abuse] should be publicized...

Such warnings were based on measures that revealed statistically significant differences between methamphetamine users and controls, which alone are insufficient to determine true cognitive dysfunctions. Nevertheless, the apparent methamphetamine abuse-cognitive impairment link has been widely publicized-numerous articles have appeared in scientific journals and the popular pressdespite the fact that it is not supported by evidence from research.

\section{IMPLICATIONS}

Many researchers in this area begin with the assumption that methamphetamine abusers exhibit cognitive dysfunction, and that their research bears this out. Findings from this review suggest that this assumption should be reevaluated to document the actual pattern of cognitive effects caused by the drug. For example, this prevailing assumption has provided the fuel for a growing number of neuroimaging studies assessing the impact of prenatal methamphetamine exposure. Hopefully, more caution will be exercised when interpreting these findings than was exercised when results were interpreted from studies of infants prenatally exposed to cocaine, who were erroneously and too readily condemned to a life of learning disabilities, psychological disturbances, and crime. From a substance-abuse treatment perspective, it has been suggested that cognitive impairments seen in methamphetamine users have the potential to compromise their ability to engage in, and benefit from, cognitive-behavioral therapy, arguably the most effective treatment (Simon et al, 2002). Findings from this review argue that such concerns are not warranted. Finally, from a public policy perspective, several governments have taken drastic measures in an effort to limit the use of methamphetamine, in part, because of the perceived pernicious effects the drug has on cognitive functioning. In Thailand, amphetamines are banned for all purposesincluding medical. In the United States, methamphetaminerelated violations are punished more harshly than those related to other illicit drugs, with the exception of crack cocaine. It is only recently that penalties associated with crack cocaine violations were reduced. This change came after nearly 25 years of criticism of the law because it was inconsistent with the scientific evidence and it exaggerated the harms associated with crack cocaine use. The monetary and human costs of this misunderstanding are incalculable.

As a final thought, note the parallel here: Many of the claims about methamphetamine-associated cognitive impairments are reminiscent of statements made about crack cocaine more than two decades ago before the empirical evidence was clear. Taken together, these observations lead us to speculate whether we are headed down this path once again.

\section{ACKNOWLEDGEMENTS}

Helpful comments were received on an earlier draft of this paper from James D Rose, Charles Ksir, David Sulzer, and Daniel Wolfe, Don Habibi. Responsibility for the content of the paper in its present form, of course, rests with the authors. The support of the Open Society Foundation and National Institute on Drug Abuse (Grant numbers DA03746 and DA-019559) is gratefully acknowledged.

\section{DISCLOSURE}

The authors declare no conflict of interest.

\section{REFERENCES}

ADA Division of Communications; Journal of the American Dental Association; ADA Division of Scientific Affairs (2005). For the dental patient ... methamphetamine use and oral health. Journal of the American Dental Association 136: 1491.

Bartholow M (2010). Top 200 prescription drugs of 2009. Pharmacy Times www.pharmacytimes.com/publications/issue/ 2010/May2010/RxFocusTopDrugs-0510, accessed 12 July 2011.

Blakeslee S (2004). This is your brain on meth: a 'forest fire' of damage. The New York Times.

Belcher AM, Feinstein EM, O'Dell SJ, Marshall JF (2008). Methamphetamine influences on recognition memory: comparison of escalating and single-day dosing regimes. Neuropsychopharmacology 33: 1453-1463.

Berman SM, Voytek B, Mandelkern MA, Hassid BD, Isaacson A, Monterosso J et al (2008). Changes in cerebral glucose metabolism during early abstinence from chronic methamphetamine abuse. Mol Psychiatry 13: 897-908.

Boileau I, Rusjan P, Houle S, Wilkins D, Tong J, Selby P et al (2008). Increased vesicular monoamine transporter binding during early abstinence in human methamphetamine users: Is VMAT2 a stable dopamine neuron biomarker? J Neurosci 28: 9850-9856.

Boone KB, Ghaffarian S, Lesser IM, Hill-Gutierrez E, Berman NG (1993). Wisconsin card sorting test performance in healthy, older adults: relationship to age, sex, education, and IQ. J Clin Psychol 49: 54-60.

Cadet JL, Krasnova IN (2009). Molecular bases of methamphetamine-induced neurodegeneration. Int Rev Neurobiol 88: 101-119.

Chang L, Cloak C, Patterson K, Grob C, Miller EN, Ernst T (2005). Enlarged striatum in abstinent methamphetamine abusers: a possible compensatory response. Biol Psychiatry 57: 967-974.

Chang L, Ernst T, Speck O, Patel H, DeSilva M, Leonido-Yee M et al (2002). Perfusion MRI and computerized cognitive test abnormalities in abstinent methamphetamine users. Psychiatry Res 114: 65-79.

Cho AK, Melega WP, Kuczenski R, Segal DS (2001). Relevance of pharmacokinetic parameters in animal models of methamphetamine abuse. Synapse 39: 161-166.

Chung A, Lyoo IK, Kim SJ, Hwang J, Bae SC, Sung YH et al (2007). Decreased frontal white-matter integrity in abstinent methamphetamine abusers. Int J Neuropsychopharmacol 10: 765-775. 
Comer SD, Hart CL, Ward AS, Haney M, Foltin RW, Fischman MW (2001). Effects of repeated oral methamphetamine administration in humans. Psychopharmacology 155: 397-404.

Cretzmeyer M, Walker J, Hall JA, Arndt S (2007). Methamphetamine use and dental disease: results of a pilot study. J Dent Children 74: 85-92.

Dobkin C, Nicosia N (2009). The war on drugs: methamphetamine, public health, and crime. Am Econ Rev 99: 324-349.

Fleckenstein AE, Voltz TJ, Riddle EL, Gibb JW, Hanson GR (2007). New insights into the mechanism of action of amphetamines. Annu Rev Pharmacol Toxicol 47: 681-698.

Gerasimov MR, Franceschi M, Volkow ND, Gifford A, Gatley SJ, Marsteller D et al (2000). Comparison between intraperitoneal and oral methylphenidate administration: a microdialysis and locomotor activity study. J Pharmacol Exp Therap 295: 51-57.

Grelotti DJ, Kanayama G, Pope Jr HG (2010). Remission of persistent methamphetamine-induced psychosis after electroconvulsive therapy: presentation of a case and review of the literature. Am J Psychiatry 167: 17-23.

Hamamoto DT, Rhodus NL (2009). Methamphetamine abuse and dentistry. Oral Dis 15: 27-37.

Han DH, Yoon SJ, Sung YH, Lee YS, Kee BS, Lyoo IK et al (2008). A preliminary study: novelty seeking, frontal executive function, and dopamine receptor (D2) Taql A gene polymorphism in patients with methamphetamine dependence. Compreh Psychiatry 49: 387-392.

Hart CL, Gunderson EW, Perez A, Kirkpatrick MG, Thurmond A, Comer SD et al (2008). Acute physiological and behavioral effects of intranasal methamphetamine in humans. Neuropsychopharmacology 33: 1847-1855.

Hart CL, Haney M, Foltin RW, Fischman MW (2002). Effects of the NMDA antagonist memantine on human methamphetamine discrimination. Psychopharmacology 164: 376-384.

Hart CL, Ward AS, Haney M, Foltin RW, Fischman MW (2001). Methamphetamine self-administration by humans. Psychopharmacology 157: 75-81.

Heaton RK, Chelune GJ, Talley JL, Kay GG, Curtiss G (1993). Wisconsin Card Sorting Test Manual-Revised and Expanded. Psychological Assessment Resource: Lutz, FL.

Henry JD, Mazur M, Rendell PG (2009). Social-cognitive difficulties in former users of methamphetamine. $\mathrm{Br} \mathrm{J}$ Clin Psychol 48: 323-327.

Ho EL, Josephson SA Lee HS, Smith WS (2009). Cerebrovascular complications of methamphetamine abuse. Neurocrit Care 10: 295-305.

Hoffman WF, Moore M, Templin R, McFarland B, Hitzemann RJ, Mitchell SH (2006). Neuropsychological function and delay discounting in methamphetamine-dependent individuals. Psychopharmacology 188: 162-170.

Hoffman WF, Schwartz DL, Huckans MS, McFarland BH, Meiri G, Stevens AA et al (2008). Cortical activation during delay discounting in abstinent methamphetamine dependent individuals. Psychopharmacology 201: 183-193.

Hyman SE, Malenka RC, Nestler EJ (2006). Neural mechanisms of addiction: the role of reward-related learning and memory. Annu Rev Neurosci 29: 565-598.

Johanson CE, Frey KA, Lundahl LH, Keenan P, Lockhart N, Roll J et al (2006). Cognitive function and nigrostriatal markers in abstinent methamphetamine abusers. Psychopharmacology 185: 327-338.

Johnson BA, Ait-Daoud N, Wells LT (2000). Effects of isradipine, a dihydropyridine-class calcium channel antagonist, on Dmethamphetamine-induced cognitive and physiological changes in humans. Neuropsychopharmacology 22: 504-512.

Johnson BA, Roache JD, Ait-Daoud N, Wallace C, Wells LT, Wang $Y$ (2005). Effects of isradipine on methamphetamine-induced changes in attentional and perceptual-motor skills of cognition. Psychopharmacology 178: 296-302.

Johnson BA, Roache JD, Ait-Daoud N, Wells LT, Wallace CL, Dawes MA et al (2007). Effects of topiramate on methamphetamine-induced changes in attentional and perceptual-motor skills of cognition in recently abstinent methamphetaminedependent individuals. Prog Neuropsychopharmacol Biol Psychiatry 3: 123-130.

Kalechstein AD, Newton TF, Green M (2003). Methamphetamine dependence is associated with neurocognitive impairment in the initial phases of abstinence. J Neuropsychiatry Clin Neurosci 15: 215-220.

Kim SJ, Lyoo IK, Hwang J, Chung A, Hoon Sung Y, Kim J et al (2006). Prefrontal grey-matter changes in short-term and longterm abstinent methamphetamine abusers. Int J Neuropsychopharmacol 9: 221-228.

Kim SJ, Lyoo IK, Hwang J, Sung YH, Lee HY, Lee DS et al (2005). Frontal glucose hypometabolism in abstinent methamphetamine users. Neuropsychopharmacology 30: 1383-1391.

Kim YT, Lee SW, Kwon DH, Seo JH, Ahn BC, Lee J (2009). Dosedependent frontal hypometabolism on FDG-PET in methamphetamine abusers. J Psychiatric Res 43: 1166-1170.

Kirkpatrick MG, Gunderson EW, Johanson CE, Levin FR, Foltin RW, Hart CL (in press a). Comparison of intranasal methamphetamine and $d$-amphetamine self-administration by humans. Addiction.

Kirkpatrick MG, Gunderson EW, Perez AY, Haney M, Foltin RW, Hart CL (in press b). A direct comparison of the behavioral and physiological effects of methamphetamine and 3,4methylenedioxymethamphetamine (MDMA) in humans. Psychopharmacology; e-pub ahead of print 12 July 2011.

Kirkpatrick MG, Metcalfe J, Greene MJ, Hart CL (2008). Effects of intranasal methamphetamine on metacognition of agency. Psychopharmacology 197: 137-144.

Lee B, London ED, Poldrack RA, Farahi J, Nacca A, Monterosso JR et al (2009). Striatal dopamine D2/D3 receptor availability is reduced in methamphetamine dependence and is linked to impulsivity. J Neurosci 29: 14734-14740.

Leland D, Arce E, Miller D, Paulus M (2008). Anterior cingulate cortex and benefit of predictive cueing on response inhibition in stimulant dependent individuals. Biol Psychiatry 63: $184-190$.

London ED, Berman SM, Voytek B, Simon SL, Mandelkern MA, Monterosso J et al (2005). Cerebral metabolic dysfunction and impaired vigilance in recently abstinent methamphetamine abusers. Biol Psychiatry 58: 770-778.

London ED, Simon SL, Berman SM, Mandelkern MA, Lichtman $\mathrm{AM}$, Bramen J et al (2004). Mood disturbances and regional cerebral metabolic abnormalities in recently abstinent methamphetamine abusers. Arch Gen Psychiatry 61: 73-84.

Marrone GF, Pardo J, Krauss RM, Hart CL (2010). Amphetamine analogs methamphetamine and 3,4-methylenedioxymethamphetamine (MDMA) differentially affect speech. Psychopharmacology 208: 169-177.

Marshall JF, Belcher AM, Feinstein EM, O'Dell SJ (2007). Methamphetamine-induced neural and cognitive changes in rodents. Addiction 102(Suppl): 61-69.

Martin WR, Sloan JW, Sapira JD, Jasinski DR (1971). Physiologic, subjective, and behavioral effects of amphetamine, methamphetamine, ephedrine, phenmetrazine, and methylphenidate in man. J Clin Pharmacol Therap 12: 245-258.

McCann UD, Kuwabara H, Kumar A, Palermo M, Abbey R, Brasic J et al (2008). Persistent cognitive and dopamine transporter deficits in abstinent methamphetamine users. Synapse 62: 91-100.

McCann UD, Wong DF, Yokoi F, Villemagne V, Dannals RF, Ricaurte GA (1998). Reduced striatal dopamine transporter density in abstinent methamphetamine and methcathinone 
users: evidence from positron emission tomography studies with $\left[{ }^{11}\right.$ C]WIN-35428. J Neurosci 18: 8417-8422.

Mitrushina M, Boone KB, Razani J, D'Elia LF (2005). Handbook of Normative Data for Neuropsychological Assessment, 2nd edn. Oxford University Press: New York, NY.

Mohs RC, Tinklenberg JR, Roth WT, Kopell BS (1978). Methamphetamine and diphenhydramine effects on the rate of cognitive processing. Psychopharmacology 59: 13-19.

Mohs RC, Tinklenberg JR, Roth WT, Kopell BS (1980). Sensitivity of some human cognitive functions to effects of methamphetamine and secobarbital. Drug Alcohol Depend 5: $145-150$.

Monterosso JR, Ainslie G, Xu J, Cordova X, Domier CP, London ED (2007). Frontoparietal cortical activity of methamphetaminedependent and comparison subjects performing a delay discounting task. Hum Brain Mapp 28: 383-393.

Mosharov EV, Larsen KE, Kanter E, Phillips KA, Wilson K, Schmitz Y et al (2009). Interplay between cytosolic dopamine, calcium, and alpha-synuclein causes selective death of substantia nigra neutrons. Neuron 62: 218-229.

O'Neil ML, Kuczenski R, Segal DS, Cho AK, Lacan G, Melega WP (2006). Escalating dose pretreatment induces pharmacodynamic and not pharmacokinetic tolerance to a subsequent high-dose methamphetamine binge. Synapse 60: 465-473.

Paulus MP, Hozack N, Frank L, Brown GG, Schuckit MA (2003). Decision making by methamphetamine-dependent subjects is associated with error-rate-independent decrease in prefrontal and parietal activation. Biol Psychiatry 53: 65-74.

Paulus MP, Hozack NE, Zauscher BE, Frank L, Brown GG, Braff DL et al (2002). Behavioral and functional neuroimaging evidence for prefrontal dysfunction in methamphetamine-dependent subjects. Neuropsychopharmacology 26: 53-63.

Payer DE, Lieberman MD, Monterosso JR, Xu J, Fong TW, London ED (2008). Differences in cortical activity between methamphetamine-dependent and healthy individuals performing a facial affect matching task. Drug Alcohol Depend 93: 93-102.

Pilley C, Perngparn U (1998). Introduction to drug use and treatments in Thailand. J Demogr Vol 14: 69-85.

Raiteri M, Cerrito F, Cervoni AM, Levi G (1979). Dopamine can be released by two mechanisms differentially affected by the dopamine transport inhibitor nomifensine. J Pharmacol Exp Therap 208: 195-202.

Rendell PG, Mazur M, Henry JD (2009). Prospective memory impairment in former users of methamphetamine. Psychopharmacology 203: 609-616.

Rush CR, Stoops WW, Lile JA, Glaser PE, Hays LR (2011). Subjective and physiological effects of acute intranasal methamphetamine during D-amphetamine maintenance. Psychopharmacology 214: 665-674.

Salo R, Nordahl TE, Buonocore MH, Natsuaki Y, Waters C, Moore CD et al (2009a). Cognitive control and white matter callosal microstructure in methamphetamine-dependent ubjects: a diffusion tensor imaging study. Biol Psychiatry 65: $122-128$.

Salo R, Ursu S, Buonocore MH, Leamon $\mathrm{MH}$, Carter C (2009b). Impaired prefrontal cortical function and disrupted adaptive cognitive control in methamphetamine abusers: a functional magnetic resonance imaging study. Biol Psychiatry 65: 706-709.

Schmitz Y, Schmauss C, Sulzer D (2002). Altered dopamine release and uptake kinetics in mice lacking $\mathrm{D}_{2}$ receptors. J Neurosci 22: 8002-8009.

Scott JC, Woods SP, Matt GE, Meyer RA, Heaton JH, Grant I (2007). Neurocognitive effects of methamphetamine: a critical review and meta-analysis. Neuropsychol Rev 17: 275-297.
Segal DS, Kuczenski R, O’Neil ML, Melega WP, Cho AK (2003). Escalating dose methamphetamine pretreatment alters the behavioral and neurochemical profiles associated with exposure to a high-dose methamphetamine binge. Neuropsychopharmacology 28: 1730-1740.

Sekine Y, Iyo M, Ouchi Y, Matsunaga T, Tsukada H, Okada $\mathrm{H}$ et al (2001). Methamphetamine-related psychiatric symptoms and reduced brain dopamine transporters studied with PET. Am J Psychiatry 158: 1206-1214.

Sevak RJ, Stoops WW, Hays LR, Rush CR (2009). Discriminative stimulus and subject-rated effects of methamphetamine, $d$-amphetamine, methylphenidate, and triazolam in methamphetamine-trained humans. J Pharmacol Exp Ther 28: $1007-1018$

Shetty V, Mooney LJ, Zigler CM, Belin TR, Murphy D, Rawson RJ (2010). The relationship between methamphetamine use and increased dental disease. J Am Dent Assoc 141: 307-318.

Shohamy D, Myers CE, Kalanithi J, Gluck MA (2008). Basal ganglia and dopamine contributions to probabilistic category learning. Neurosci Biobehav Rev 32: 219-236.

Silber BY, Croft RJ, Papafotiou K, Stough C (2006). The acute effects of $d$-amphetamine and methamphetamine on attention and psychomotor performance. Psychopharmacology 187: 154-169.

Simon SL, Dean AC, Cordova X, Monterosso JR, London ED (2010). Methamphetamine dependence and neuropsychological functioning: evaluating change during early abstinence. J Stud Alcohol Drugs 71: 335-344.

Simon SL, Domier C, Carnell J, Brethen P, Rawson R, Ling W (2000). Cognitive impairment in individuals currently using methamphetamine. Am J Addict 9: 222-231.

Simon SL, Richardson K, Dacey J, Glynn S, Domier CP, Rawson RA et al (2002). A comparison of patterns of methamphetamine and cocaine use. J Addict Dis 21: 35-44.

Sonders MS, Zhu S, Zahniser NR, Kavanaugh MP, Amara SG (1997). Multiple ionic conductances of the human dopamine transporter: the actions of dopamine and psychostimulants. J Neurosci 17: 960-974.

Sitte HH, Huck S, Reither H, Boehm S, Singer EA, Pifl C (1998). Carrier-mediated release, transport rates, and charge transfer induced by amphetamine, tyramine, and dopamine in mammalian cells transfected with the human dopamine transporter. J Neurochem 71: 1289-1297.

Sulzer D, Sonders MS, Poulsen NW, Galli A (2005). Mechanisms of neurotransmitter release by amphetamines: a review. Progr Neurobiol 75: 406-433.

Talland GA, Quarton GC (1965). The effects of methamphetamine and pentobarbital on the running memory span. Psychopharmacologia 7: 379-382.

Thompson PM, Hayashi KM, Simon SL, Geaga JA, Hong MS, Sui Y et al (2004). Structural abnormalities in the brains of human subjects who use methamphetamine. J Neurosci 24: 6028-6036.

UN Global ATS Assessment (2008). Amphetamines and ecstasy. United Nations Office of Drug and Crime.

Volkow ND, Chang L, Wang GJ, Fowler JS, Franceschi D, Sedler MJ et al (2001a). Higher cortical and lower subcortical metabolism in detoxified methamphetamine abusers. Am J Psychiatry 158: 383-389.

Volkow ND, Chang L, Wang GJ, Fowler JS, Leonido-Yee M, Franceschi D et al (2001b). Association of dopamine transporter reduction with psychomotor impairment in methamphetamine abusers. Am J Psychiatry 158: 377-382.

Volkow ND, Chang L, Wang GJ, Fowler JS, Ding YS, Sedler M et al (2001c). Low level of brain dopamine D2 receptors in methamphetamine abusers: association with metabolism in the orbitofrontal cortex. Am J Psychiatry 158: 2015-2021. 


\section{Cognitive functioning and methamphetamine}

CL Hart et al

Volkow ND, Chang L, Wang GJ, Fowler JS, Franceschi D, Sedler M et al (2001d). Loss of dopamine transporters in methamphetamine abusers recovers with protracted abstinence. J Neurosci 21: 9414-9418.

Wang GJ, Volkow ND, Chang L, Miller E, Sedler M, Hitzemann R et al (2004). Partial recovery of brain metabolism in methamphetamine abusers after protracted abstinence. Am J Psychiatry 161: $242-248$.
Zaczek R, Culp S, De Souza EB (1991a). Interactions of $\left[{ }^{3} \mathrm{H}\right]$ amphetamine with rat brain synaptosomes. II. Active transport. J Pharmacol Exp Therap 257: 830-835.

Zaczek R, Culp S, Goldberg H, Mccann DJ, De Souza EB (1991b). Interactions of $\left[{ }^{3} \mathrm{H}\right]$ amphetamine with rat brain synaptosomes. I. Saturable sequestration. J Pharmacol Exp Therap 257: 820-829. 